\title{
Corporate Social Responsibility and its Impact on Financial Performance: Investigation of U.S. Commercial Banks
}

\author{
Marcia Millon Cornett ${ }^{\mathrm{a}}$, Otgontsetseg Erhemjamts ${ }^{\mathrm{a}}$, Hassan Tehranian ${ }^{\mathrm{b} *}$ \\ ${ }^{a}$ Department of Finance, Bentley University, Waltham, MA 02452 USA \\ ${ }^{b}$ Carroll School of Management, Boston College, Chestnut Hill, MA 02467 USA
}

January 2014

\begin{abstract}
This paper analyzes corporate social responsibility (CSR) for banks and its impact on bank financial performance in a context of the recent financial crisis. The largest banks consistently have higher CSR strengths and CSR concerns during the sample period. However, this group sees a steep increase in CSR strengths and a steep drop in CSR concerns after 2009. Banks that are profitable, have higher capital ratios, charge lower fees to deposits, and with more female and minority directors have significantly higher CSR strengths scores. For banks with low involvement in low income communities, it is the smallest banks that show many significant relations between corporate social responsibility and bank characteristics. Yet, for banks with high involvement in low income communities, it is the largest banks that show many significant relations. Finally, we find that the largest banks appear to be rewarded for their social responsibility, as both industry adjusted ROA and ROE are positively and significantly related to CSR scores.
\end{abstract}

JEL Classification: G21, L21, L25, M14

Keywords: corporate social responsibility, firm performance, commercial banks

The authors are grateful to Jim Booth, Atul Gupta, Oguzhan Karakas, Darren Kisgen, Alan Marcus, Phil Strahan, and seminar participants at Bentley University and Boston College for their helpful comments.

* Corresponding author. Tel.: +1 617 552-3944.

E-mail addresses: mcornett@bentley.edu (M.M. Cornett), oerhemjamts@bentley.edu (O. Erhemjamts), hassan.tehranian@bc.edu (H. Tehranian). 


\section{Corporate Social Responsibility and its Impact on Financial Performance: Investigation of U.S. Commercial Banks}

\section{Introduction}

The global economy continues its recovery from the worst recession since the 1930s. While there are a number of positive signs that the economy is slowly improving, the role the financial industry played in this crisis is widely discussed and recognized. Banks' goal of obtaining large profits has been noted as the reason behind the advancement of financial innovations and risky speculations, the expansion of loans and, particularly, subprime mortgages, the increase in asset prices without economic basis, and eventually, the sudden and unexpected decrease in financial asset prices that lead to the financial crisis. As financial institutions work with policymakers and others in the private sector to restore growth and build public goodwill going forward, the issues of corporate social responsibility (CSR) and its impact on financial performance are more relevant than ever.

The aftereffects of the financial crisis and the slow economic recovery have resulted in increased skepticism and constant scrutiny of commercial banks' motives and actions. Consumers want tangible actions that demonstrate that banks have their interests at heart. The emergence of social media has empowered consumers: showcasing what they want and demanding immediate response from banks. Nationwide campaigns, such as Bank Transfer Day

on November 5, 2011, encouraged consumers to leave their "big" banks for credit unions and community banks. Communities and local governments (e.g., New York City, Los Angeles, Boston, and San Diego) are also pressuring and requiring banks to offer better services in poor neighborhoods, and to submit community reinvestment plans regularly, in order to do business with them (The New York Times, May 14, 2012). 
There is some anecdotal evidence that banks are taking social responsibility more seriously after the financial crisis. For example, in August 2012, Bank of America released its second annual CSR report. The report highlights a number of initiatives such as Bank of America’s ten-year, \$1.5 trillion community development lending and investing goal; ten-year, $\$ 2$ billion philanthropic investment goal; and ten-year, \$50 billion environmental business goal. In September 2012, J.P. Morgan Chase released a full set of corporate responsibility reports, highlighting the firm's global efforts to help grow the economy, strengthen the communities in which it operates, expand educational opportunity, and promote environmental sustainability.

The empirical relation between corporate social responsibility and corporate financial performance is not well established in the literature. Despite more than 30 years of research and more than 100 empirical studies on the issue, the results are mixed (see, for example, Griffin and Mahon, 1997; Margolis and Walsh, 2003; Garcia-Castro et al., 2010; Dimson et al., 2013). While the relation between CSR and financial performance has not been extensively examined in the banking industry, the existing few studies offer conflicting evidence (e.g., Chih et al., 2010; Wu and Shen, 2013). Given the mixed results of previous studies and the incentive for banks to improve their reputations after the financial crisis, an examination of bank CSR activities surrounding the crisis would be of particular interest for assessing banks' efforts at being more socially responsible.

In this paper, we investigate whether commercial banks in aggregate are taking substantive steps at being socially responsible, if their socially responsible activities have changed since the financial crisis, and whether they are being rewarded for their actions. We use publicly available data on CSR to analyze CSR strengths and CSR concerns. We find that the largest banks consistently have higher CSR strengths and CSR concerns during the sample 
period. Further, this group sees a steep increase in CSR strengths and a steep drop in CSR concerns after 2009, as the worst of the financial crisis passed. We also find that more profitable banks, banks with higher capital ratios, and banks that charge lower fees on deposits have significantly higher CSR strengths. We find that banks with more females and minorities on the board of directors have significantly higher CSR strengths. Finally, for banks that have low involvement in low income communities, it is the smallest banks that show many significant relations between corporate social responsibility and bank characteristics. Yet for banks that have high involvement in low income communities, it is the largest banks that show many significant relations. Examining the relation between CSR and bank performance, we find that the largest banks appear to be rewarded for being social responsibility, as both industry adjusted ROA and ROE are positively and significantly related to CSR scores. Thus, after the financial crisis, the biggest banks that have been accused of putting their own interests ahead of their customers and the financial system as a whole worked to repair their reputations by turning to more socially responsible activities. For these banks, engaging in socially responsible activities do appear to result in improved financial performance.

The remainder of the paper is organized as follows. Section 2 recaps the literature on the relation between corporate social responsibility and firm performance and presents our hypotheses. Section 3 describes the data and methodology used in the analysis. Section 4 discusses the results of the analysis. Finally, Section 5 concludes the paper.

\section{Related Literature and Hypotheses Development}

While many papers have examined the relation between firms' socially responsible behavior and their financial performance, the results of these studies are mixed. In a meta-study on the relation between CSR and firm performance, Margolis and Walsh (2003) review 109 
studies where CSR is treated as the independent variable, predicting firm performance. They conclude that out of these 109 studies, 54 show a positive relationship, 20 show mixed results, 28 studies report nonsignificant relationships, and 7 studies report a negative relationship. The authors note that possible reasons for the lack of consensus include drawbacks related to measurement issues and model misspecifications. More recently, a growing literature contends that firms pursue profit maximizing CSR (e.g., Bénabou and Tirole, 2010: Gillan et al., 2010).

In addition to performance, studies have looked at how CSR impacts firm value. Here the results are more consistent, finding that CSR activities positively affect value. For example, Servaes and Tamayo (2013) show that CSR and firm value are positively related for firms with high customer awareness (as is the case for banks during the financial crisis). Dimson et al. (2012) find that firms are more likely to undertake CSR and CSR is more likely to be value enhancing if the firm is concerned about its reputation (also the case for banks during the financial crisis) and if it has higher capacity to implement changes. ${ }^{1}$ El Ghoul et al. (2011) find that firms with better CSR scores exhibit cheaper equity financing, while Goss and Roberts (2011) find that more socially responsible firms pay between 7 and 18 basis points less than firms with social responsibility concerns.

Moreover, Boulash et al. (2013) find that firm risk for S\&P500 companies increases with employee, diversity, and corporate governance concerns. ${ }^{2}$ Albuquerque et al. (2011) show that

\footnotetext{
${ }^{1}$ Similarly, Hong and Kacperczyk (2009) find that find that stocks of companies involved in producing alcohol, tobacco, and gaming are less held by norm-constrained institutions such as pension plans as compared to mutual or hedge funds that are natural arbitrageurs, and they receive less coverage from analysts than do stocks of otherwise comparable characteristics. Heinkel et al. (2001) find that ethical investing leads to polluting firms being held by fewer investors, and as a result lower stock prices, since green investors avoid polluting firms' stock. Finally, Hong and Kostovetsky (2012) find that mutual fund managers who make campaign donations to Democrats hold less of their portfolios (relative to nondonors or Republican donors) in companies that are deemed socially irresponsible (e.g., tobacco, guns, or defense firms or companies with bad employee relations or diversity records).

${ }^{2}$ Further, Edmans (2011) finds that a firm's concern for other stakeholders, such as employees, may ultimately benefit shareholders. Bae et al. (2011) find that a firm's incentive or ability to offer fair employee treatment is an important determinant of its financing policy.
} 
CSR reduces firm systematic risk and that profits are less correlated with the business cycle for CSR firms than for non-CSR firms. Galema et al. (2008) find that socially responsible investing (SRI) impacts stock returns by lowering the book-to-market ratio. Jiao (2010) constructs a stakeholder welfare score to measure the extent to which firms meet the expectation of their nonshareholder stakeholders (such as employees, customers, communities, and environment), and finds it to be associated with positive valuation effects. Finally, Aktas et al. (2011) document a positive relation between acquirer gains and the level of the target's social and environmental risk management practices. Their findings suggest that acquirers are rewarded for making socially and environmentally responsible investments.

As for the banking industry, the relation between corporate social responsibility and financial performance has not been examined extensively, and the few existing studies offer conflicting evidence. For example, Chih et al. (2010) investigate a total of 520 financial firms in 34 countries over 2003-2005, and conclude that CSR and financial performance are not related. In contrast, Wu and Shen (2013) analyze 162 banks in 22 countries over 2003-2009, and report that CSR is positively associated with financial performance in terms of return on assets, return on equity, net interest income, and noninterest income. Differences in the results could be related to measurement issues, differences in sample as well as sample period.

Therefore, to analyze banks' social performance and its' impact on their financial performance in a context of the recent financial crisis, we develop the following set of research questions and associated testable hypotheses.

Research question 1: What are the determinants of banks' social performance?

Larger banks tend to draw a higher level of attention from the public, and have greater social impact, suggesting that larger banks are more likely to have stronger CSR scores. On the 
other hand, smaller banks may seek for differentiation and access to new markets, and therefore invest more in socially responsible activities. In addition, effectiveness of corporate governance may affect bank's social performance. Therefore, we examine the measures of board composition and their impact on CSR. Banks with a higher proportion of independent directors, and less powerful CEOs are expected to have stronger CSR scores. We also expect geographic area to play a role. Banks with geographic focus on low income communities and individuals are expected to have stronger CSR scores.

Research question 2: How did the social performance of banks change over time?

The aftereffects of the crisis and the slow economic recovery resulted in increased skepticism and constant scrutiny of commercial banks' motives and actions. Consumers, communities, and local governments lost faith in their banks and seek tangible actions to demonstrate that banks have their interests at heart. To address these concerns, banks are increasingly setting long-term goals for community development, philanthropy, environmental sustainability (e.g., Bank of America, Wells Fargo, and JP Morgan and Chase). Given these changes, social performance of banks is expected to improve in the post-crisis period, compared to precrisis period. Improvements in CSR for banks with better corporate governance and for banks with geographic focus on low income communities and individuals are expected to be greater.

Research question 3: How does banks' social performance impact their financial performance?

A number of theoretical perspectives have been examined in the literature on the relation between CSR and firm financial performance. Bénabou and Terole (2010) offer three visions of CSR. Vision 1: 'Win-win' ('doing well by doing good') posits that being a good corporate citizen can also make a firm more profitable. Vision 2: ‘Delegated philanthropy’ states that some 
stakeholders (investors, customers, employees) are often willing to sacrifice money (yield, purchasing power and wage, respectively) so as to further social goals. That is, stakeholders have some demand for corporations to engage in philanthropy on their behalf. Under this vision, the corresponding CSR profit sacrifice is passed through to stakeholders at their demand. Vision 2 of CSR maximizes profit given the demand of stakeholders. As with the long-term perspective, profit maximization and CSR are consistent. Vision 3: 'Insider-initiated corporate philanthropy’ theorizes that corporate social behavior reflects management's desires to engage in philanthropy. In this vision, profit is not necessarily maximized. However, with effective corporate governance in place, this vision of CSR should not be predominant. Rather, effective stakeholder management can enhance a firm's ability to achieve a competitive advantage and long-term value creation. Therefore, a positive relation is expected between banks' social and financial performance.

Research question 4: How did the relation between banks' social performance and their financial performance change over time?

In the aftermath of the 2008-2009 financial crisis, the interest in understanding social responsibility in the interplay of financial markets and the real economy has reached unprecedented momentum (Puaschunder, 2012). Financial market regulators and consumer protection agencies have set out to reestablish trust in the corporate and financial world. In July 2010, the U.S. Congress approved a sweeping expansion of federal financial regulation in response to the "the financial excesses" that caused the worst recession since the Great Depression (The New York Times, July 15, 2010). The new "Report on Sustainable and Responsible Investing Trends in the United States,” released in November 2012 by the U.S. SIF Foundation, finds that sustainable and responsible investing (SRI) increased by 22 percent since year end 2009. This trend reflects growing investor interest in considering environmental, 
societal, or corporate governance (ESG) issues to refine how they make decisions as they select and manage their portfolios or raise their voices as shareholders. Additionally, the U.S. SIF Foundation identified many investors that are beginning to develop in-house capabilities to analyze ESG criteria. Therefore, the relation between banks' social performance and their financial performance is expected to be stronger in the post-crisis period compared to the precrisis period.

\section{Research Methodology}

\subsection{Data}

We first collect environmental, social, and governance (ESG) ratings of the largest 3,000 publicly traded companies from the MSCI ESG STATS ${ }^{3}$ database over 2003-2011 period. We choose 2003 as a starting point because that is when KLD coverage expands from 1,000 largest companies to 3,000 largest companies. We then merge the ESG ratings data for financial institutions with the Consolidated Report of Condition and Income (i.e., Call Reports) database from Federal Financial Institutions Examination Council (FFIEC). This combined dataset is the base for all our analyses. Eliminating banks with only one year of ESG rating observations results in 1,712 bank-year observations with an average of 190 banks per year. ${ }^{4}$

\section{1.a. Measures of CSR}

MSCI ESG STATS evaluates companies on 56 indicators to capture "strengths” and “concerns” attributes in seven categories that include community, diversity, employee relations, environment, human rights, products, and governance. The MSCI ESG STATS product utilizes a

\footnotetext{
${ }^{3}$ MSGI ESG STATS database is formerly known as KLD database. KLD Research and Analytics was acquired by RiskMetrics Group in 2009, and RiskMetrics Group was later acquired by MSCI in 2010. MSCI ESG Research consolidated ESG ratings indicators substantially in the 2010 research cycle. This can be seen most prominently with the "concern" ESG indicators.

${ }^{4}$ In contrast to our dataset, Wu and Shen (2013) examine 162 banks, of which 31 are U.S. banks. Further, their dataset ends in 2009, while ours runs through 2011, which allows us to look at CSR activities of banks before versus after the financial crisis.
} 
binary representation of ESG ratings. If a company does meet the criteria established for a rating, this is indicated with a "1." If a company does not meet the criteria established for a rating, this is indicated with a " 0 ." These values are then summed across each category on strength and concern attributes. We construct variables All Strengths as the sum of all ESG scores on attributes that are identified as strengths and All Concerns in an analogous manner. Following Hillman and Keim (2001) and Garcia-Castro et al. (2010) we assign equal importance to the ESG categories and construct the variable ESG Index (formerly known as KLD index), our measure of overall CSR, by subtracting All Concerns from All Strengths.

Despite its popularity, the ESG index suffers from an aggregation problem. For example, by netting the total score on concerns from the strengths' score, a firm with ten strengths and ten concerns across all categories is deemed to have a same level of social responsibility as a firm with one strength and one concern. Erhemjamts et al. (2012) argue that this loss in heterogeneity can be mitigated by decomposing the ESG index into its strengths and concerns components. Therefore, following Erhemjamts et al. (2012), we use All Strengths and All Concerns as CSR measures in addition to the overall ESG index.

Figure 1 shows a time series (2003 through 2011) of the ESG All Strengths and All Concerns and Table 1 presents descriptive statistics of these scores for the sample banks. We examine the sample banks based on three size groups consistent with FDIC size groupings: total assets less than $\$ 10$ billion, total assets between $\$ 10$ billion and $\$ 100$ billion, and total assets greater than $\$ 100$ billion. From Figure 1 we see that the largest banks consistently have higher All Strengths and All Concerns scores during the sample period. However, this group sees a steep increase in All Strengths and a steep drop in All Concerns after 2009, as the worst of the financial crisis passed. 
Table 1 confirms that the changes surrounding the financial crisis are significant. In addition to the overall ESG Index, we report the descriptive statistics for All Strengths, All Concerns, as well as strengths and concerns in all seven categories: community, environment, diversity, employee relations, human rights, product, and corporate governance. Consistent with Figure 1, we see in Table 1 that banks in the largest size group (total assets greater than or equal to $\$ 100$ billion) have the highest scores for both strength and concern dimensions. In addition, areas with the highest strength and concern scores seem to be quite different for banks in different size groups. For example, for the years 2003 through 2009, corporate governance strengths are the biggest contributor to the All Strengths score for the banks in the smallest size group. In contrast, diversity strengths are the biggest contributor to the All Strengths score for the banks in the largest size group. In sum, the differences that are seen in Table 1 highlight the importance of examining CSR by size group.

For the largest banks, All Strengths increases from an average 5.96 in 2003-2009 to 9.31 in 2010-2011 (significant at 1\%). The increase in the overall score is driven by a significant increase in each of the 7 individual components. Further, for the largest banks, All Concerns decreases from an average 4.32 in 2003-2009 to 3.42 in 2010-2011. While the difference in the overall score is insignificant, we do see a significant drop in community concerns from 0.55 in 2003-2009 to 0.12 in 2010-2011. During the financial crisis, banks (particularly the largest banks) were criticized for a lack of concern of their customers. According to this measure, it appears that these large banks worked to reduce this criticism after the crisis. From Table 1, we also see that, for the smallest banks, All Strengths decreases from an average 1.19 in 2003-2009 to 0.14 in $2010-2011$ (significant at $1 \%$ ). The decrease in the overall score is driven by a significant decrease in 6 of the 7 individual components (only the human rights score does not 
decrease). Further, for the smallest banks, All Concerns increase from an average 0.69 in 20032009 to 2.00 in 2010-2011, while for middle-sized banks All Concerns increase from an average 1.24 in 2003-2009 to 1.77 in 2010-2011 (both are significant at 1\%). Thus, while the largest banks see improvements in their corporate social responsibility scores around the financial crisis, smaller banks seem to deteriorate.

\section{1.b. Measures of bank performance}

We use two measures of bank profitability, industry adjusted ROA and industry adjusted ROE. More specifically, we calculate the industry average ROA and ROE using all banks in the Call Reports. We then group banks by size of total assets (less $\$ 10$ billion, between $\$ 10$ billion and $\$ 100$ billion, and greater than $\$ 100$ billion) and subtract the size-adjusted industry average of the non-sample banks from the ROA and ROE of the bank in question to arrive at the industry adjusted financial performance measures.

Figure 2 shows a time series pattern in industry adjusted ROA (panel A) and ROE (panel B) for our sample banks from 2003 through 2011. As seen in Figure 2, all banks in the sample experienced a decline in financial performance during the financial crisis. However, performance recovers to the precrisis level in 2010-2011 period. The smallest banks (total assets less than $\$ 10$ billion) show the biggest decline in performance, while the biggest banks (total assets greater than or equal to $\$ 100$ billion) show the smallest decline and the most rapid recovery.

\section{1.c. Fees to Deposits, Percentage of Low Income Counties Served}

Due to the low interest rate environment and slow economic growth, banks are under enormous pressure to find new sources of income. As a result, banks are paying more attention to their revenue from bank service fees such as ATM fees, checking account fees, and maintenance fees. Many big banks, including Bank of America, J.P. Morgan Chase, and Wells Fargo, have 
rolled out plans that aim to raise fee revenue or push customers to do more business with the bank. In response, customers are increasingly turning to social media to get their complaints heard. For example, in 2011 Bank of America had to retreat from a new \$5 debit card fee following a customer revolt and a wave of criticism. Therefore, we examine how bank fees, scaled by total deposits, affect banks’ CSR.

In addition, in an effort to measure the effect of banks' presence in low income neighborhoods, and its impact on banks' CSR, we collect summary of deposits data from the FDIC. The Summary of Deposits (SOD) is the annual survey of branch office deposits for all FDIC-insured institutions. We aggregate this branch level deposits data at the county level, and merge it with county level poverty estimates from the Small Area Income \& Poverty Estimates (SAIPE) data provided by the Census Bureau. If the percentage of all ages in poverty in a county is above the federal poverty rate, we define that county as a low income county. We then calculate the percentage of bank deposits that come from low income counties for each bank and year. Since percent of deposits is likely to be small for branches in low income communities, we also calculate percentage of low income communities served by dividing the number of low income counties served by total number of counties served for each bank and year.

\section{1.d. Board Composition Variables}

Effectiveness of corporate governance may impact firms’ involvement in CSR programs. Wang and Coffey (1992) document a positive relationship between several measures of board composition (ratio of insiders to outsiders, percentage of stock ownership, and the proportion of female and minority board members) and firms’ charitable contributions. Similarly, Fich et al. (2009) find that bigger firms with higher levels of free cash flow, larger boards, busy outside directors, and a higher governance index (higher level of the index indicates weaker governance) 
are more likely to make charitable donations. ${ }^{5}$ Therefore, we use measures of board composition from RiskMetrics Directors database (percentage of independent directors, percentage of female and minority board members, CEO-chair duality, and median tenure of directors) as a proxy for the level of corporate governance in the firm. When RiskMetrics data are not available, we supplement the board composition data with hand-collected data from proxy statements. We hypothesize that better governed firms will have better social performance.

Table 2 presents descriptive statistics for all variables used in the analysis. Panel A reports descriptive statistics for the whole sample (277 unique banks in the combined MSCI ESG STATS and Call Reports database) for 2003-2011 period and panel B reports descriptive statistics for a subsample of 160 banks with governance variables available. Median values of All Strengths and All Concerns scores are both one, highlighting the importance of decomposing the overall ESG index into its strength and concern components. The sample banks range in size from $\$ 120$ million to $\$ 1.93$ trillion and have average total assets of $\$ 38.89$ billion. The average industry adjusted ROA for the sample over the entire period (2003-2011) is $-0.16 \%$ (ranging from $-36.11 \%$ to $5.50 \%$ ). Tier 1 capital averages $11.51 \%$, ranging from $3.51 \%$ to $61.58 \%$. While on average the banks appear to be well capitalized, the financial crisis appears to have hurt some of the sample banks in terms of both ROA and capitalization. Fees charged as a percent of deposits averages $0.53 \%$, ranging from $0 \%$ to $3.67 \%$. Given that excessive fees charged on deposits have been a contentious issue at banks, and fees seem to be a small percentage of deposits, we create a dummy variable called High Fees Dummy to define banks that charge

\footnotetext{
${ }^{5}$ Masulis and Reza (2013) find that corporate giving is positively (negatively) associated with CEO charity preferences (CEO shareholdings and corporate governance). The results indicate that firm donations advance CEO interests and suggest that misuse of corporate resources reduces firm value. Finally, Cheng et al. (2013) find that improvements in managerial incentives and governance lead to a reduction in firm "goodness spending," implying that the marginal dollar spent on goodness is a result of agency problems.
} 
excessive fees. This dummy variable takes a value of one if a bank's fees as a percentage of deposits are above the sample median (0.47\%) and zero otherwise. Corporate social responsibility encompasses issues associated with how banks address issues pertaining to customers in their local community, include the charging of excessive fees on deposits. Corporate social responsibility also encompasses the extent to which banks do business in low income communities. On average, the percentage of low income counties to all counties served by banks in the sample is $41.93 \%$.

For the subsample of banks with governance data, an average of $74.87 \%$ of the board directors are independent (ranging from $27.27 \%$ to $100.00 \%$ ). On average, the boards of directors include $17.23 \%$ females and minorities (ranging from $0.00 \%$ to $122.22 \%$ ). ${ }^{6}$ The CEO and Chairman of the Board are separated in $44.55 \%$ of the sample banks. Finally, the mean tenure of the board directors is 9.39 years (ranging from 2 years to 26 years). Higher levels of independent directors, females and minorities on the board, and CEO/chair separation have been found to be associated with better financial performance at firms. We will examine whether these characteristics also are associated with better corporate social performance.

\subsection{Estimation methods}

The dataset used to test all our hypotheses is longitudinal or a panel data set. Thus, we have more than one year of data for firms in our study. This presents a few econometric challenges. First, it is likely that residuals are serially correlated, especially for the same firm. We mitigate this concern by clustering all the standard errors at the firm level. Clustering effectively provides us with a "conservative” estimate of the standard error (Petersen, 2009). The second issue is the presence of arbitrary heteroskedasticity. We address this by ensuring that all our standard errors are White-Huber "robust" to the presence of arbitrary heteroskedasticity

\footnotetext{
${ }^{6}$ If there is a director who is female, and of minority group, that particular director gets counted twice.
} 
(White, 1980). The robust option relaxes the assumption that the errors are identically distributed, while cluster relaxes the assumption that the error terms are independent of each other. Thus, we have robust standard errors that are clustered at the firm level.

Finally, certain macroeconomic factors such as interest rates, unemployment, and GDP growth change over time. These variables could directly affect the dependent variables in our study resulting in a spurious relation between the explanatory and the dependent variables (such as firm performance or capital). We follow the standard practice of including year dummy variables in the estimation procedure to alleviate this possibility. These steps ensure that our results are based on tests that robustly address deviations from standard regression assumptions.

\section{2.a. Determinants of CSR}

We first examine the determinants of CSR by estimating the following OLS regressions where independent variables include firm characteristics. Our main measures of CSR are ESG Index, All Strengths, and All Concerns.

$$
\begin{aligned}
& \operatorname{CSR}_{\text {it }}=\alpha+\beta_{\mathbf{1}} \times \text { Bank Perf }_{\mathrm{i}, \mathrm{t}-\mathbf{1}}+\beta_{\mathbf{2}} \times \text { Size }_{\mathrm{it}}+\beta_{\mathbf{3}} \times \text { Size } \text { Squared }_{\text {it }}+\boldsymbol{\beta}_{\mathbf{4}} \times \text { Tier } \mathbf{1} \text { Cap Ratio }+ \\
& +\beta_{5} \times \text { Fees to Deposits Ratio it }+\beta_{6} \times \text { Pct. Low Income Counties }+ \\
& +\delta \times \text { Board Composition }+\eta \times \text { Year Dummies }+\varepsilon \text { it } \text {. }
\end{aligned}
$$

Firm characteristics included above are largely based on the existing literature. For instance, larger firms tend to draw a higher level of attention from the public and have greater social impact (Cowen, et al., 1987), suggesting that larger firms are more likely to engage in CSR. Udayasankar (2008) argues that either very small or very large firms are equally motivated to participate in CSR, proposing a U-shaped relationship between firm size and CSR participation. To capture the presence of such nonlinearity, we include Size (log of total assets) and Size Squared in our analysis of the determinants of CSR participation. 
A firm's propensity to engage in socially responsible activities also depends on its financial health. We measure firm's financial strength by Tier 1 Capital Ratio. The Tier 1 capital ratio is the ratio of a bank's core equity capital to its total risk-weighted assets. Risk-weighted assets are the total of all assets held by the bank weighted by credit risk according to a formula determined by the Board of Governors of the Federal Reserve System. The metric is primarily used to indicate the ability of the bank (or other institutions that hold reserves) to absorb unexpected losses. We hypothesize that firms' involvement in socially responsible programs is positively related to their financial strength.

\section{2.b. Effects of CSR on Firm Performance}

We examine the effects of CSR on firm performance using the following IV-GMM regressions:

$$
\text { Bank Perf } f_{i t}=\alpha+\beta \times \operatorname{CSR}_{i t}+\delta \times \text { Control Variables }{ }_{i t}+\eta \times \text { Year Dummies }+\varepsilon_{i t} \text {; }
$$

to address the endogeneity concerns discussed in Garcia-Castro et al. (2010). IV-GMM is an instrumental variables estimator implemented using the Generalized Method of Moments (GMM). Conventional IV estimators such as two-stage least squares (2SLS) are special cases of this IV-GMM estimator. For an exactly-identified model, the efficient GMM and traditional IV2SLS estimators coincide, and under the assumptions of conditional homoskedasticity and independence, the efficient GMM estimator is the traditional IV-2SLS estimator (Hayashi, 2000).

The choice of instruments is drawn from the set of CSR determinants in the first stage regression that satisfy both the relevance (strength of instrument) and validity (exogeneity with bank performance) criteria. Since we have an over-identified model where number of excluded instruments is greater than the number of included endogenous variables, we use IV-GMM 
estimator, because IV-GMM cluster-robust estimates will be different and more efficient than robust 2SLS estimates in an over-identified model. Control variables include lagged, industry adjusted ROA (or ROE), and the Crisis dummy, which takes value of one in years 2008 and 2009 and zero otherwise.

\section{Results}

\subsection{CSR Regressions}

\section{1.a. Full Sample Results}

Table 3 reports results of OLS regressions examining the determinants of CSR. Since all results with industry adjusted ROE are similar to those with industry adjusted ROA, we only report the CSR regressions with industry adjusted ROA as a bank performance measure. Panel A reports results for the full sample period (2003-2011), panel B looks at the period before and during the height of the financial crisis (2003-2009), and panel C reports results for 2010-2011 (after the worst of the financial crisis had passed). In all panels, regressions 1-3 use the full sample of banks, while regressions 4-6 use the sample of banks on which we have corporate governance data. Regressions 1 and 4 use the overall ESG Index, regressions 2 and 5 use All Strengths only, and regressions 3 and 6 use only All Concerns.

From panel A, it appears that regressions separating the ESG index by strengths and concerns produce varied results, i.e., results with the ESG index are much weaker than those with the All Strengths and All Concerns variables. As mentioned earlier, the ESG index suffers from an aggregation problem. Thus, this is not surprising and leads us to concentrate our discussion on regressions that isolate All Strengths versus All Concerns. From regression 2, we see that larger banks have lower All Strengths scores (the coefficient on log total assets is -7.568, significant at 1\%). However, the relation is not linear. Rather, the relation is reversed for the biggest banks (the 
coefficient on log total assets squared is 0.259 , significant at $1 \%$ ). This is consistent with the Udayasankar (2008)'s argument that CSR matters for either very small or very large firms. We also see that more profitable banks (coefficient on ROA industry adjusted is 7.005), banks with higher capital ratios (coefficient on Tier 1 capital ratio is 5.511), and banks that charge lower fees to deposits (coefficient on high fees dummy variable is -0.321) have significantly higher All Strengths scores. Finally, All Strengths scores decrease significantly for the full sample of banks in 2010-2011 (coefficient on post crisis dummy is -0.728). Except for the high fees dummy, these results hold up with the inclusion of corporate governance variables, in regression 5. Further, we find that banks with more female and minority directors have significantly higher All Strengths scores (coefficient on \% females \& minority directors is 3.178).

From regression 3, we see fewer of the firm characteristics explain All Concerns scores. Larger banks again have significantly lower All Concerns scores (the coefficient on log total assets is -5.371) and again, the relation is reversed for the biggest banks (the coefficient on log total assets squared is 0.178 ). For the full sample, banks with higher capital ratios have a higher All Concerns scores (coefficient on Tier 1 capital ratio is 3.008) and the All Concerns scores increase significantly in 2010-2011 (coefficient on post crisis dummy is 0.847). When corporate governance variables are added, regression 6 , these relations continue to hold. Further, we find that banks with more female and minority directors have significantly lower All Concerns scores (coefficient on \% females \& minority directors is -0.591).

From panels $\mathrm{B}$ and $\mathrm{C}$, we see that some variations exist across time periods. Concentrating on regressions 5 and 6, more profitable banks have significantly higher All Strengths scores after the crisis (coefficient on ROA industry adjusted is 40.359, significant at $1 \%$, in panel $\mathrm{C}$ ), but this is not the case before and during the crisis (coefficient on ROA industry 
adjusted is 7.566, insignificant, in panel B). Also, banks with higher capital ratios have significantly higher All Strengths scores after the crisis (coefficient on Tier 1 capital ratio is 12.669, significant at $1 \%$, in panel C), but not before and during (coefficient on Tier 1 capital ratio is 2.238, insignificant, in panel B). Moreover, banks that charge lower fees to deposits have significantly higher All Strengths scores after the crisis (the coefficient on the high fees dummy is -0.736 , significant at $10 \%$, in panel C), but not before and during (coefficient on high fees dummy is 0.119, insignificant, in panel B). Conversely, banks with more female and minority directors have significantly higher All Strengths scores before and during the crisis, but not after the crisis (coefficient on $\%$ female $\&$ minority directors is 3.920 , significant at $1 \%$, in panel B, and 1.658, insignificant, in panel C). Finally, banks with more independent directors and shorter tenured directors have significantly higher All Strengths scores after the crisis, but not before and during the crisis (coefficient on \% independent director is 2.585 and on director tenure is -0.066 , significant at $10 \%$, in panel C, and are -0.264 and 0.003 , respectively, insignificant, in panel B).

From regression 6, banks with fewer independent directors and shorter tenured directors have significantly higher All Concerns scores after the crisis, but not during and before (coefficient on \% independent directors is -1.503 , significant at 5\%, while coefficient on director tenure is -0.060 , significant at $1 \%$, in panel $\mathrm{C}$, and are 0.159 and 0.005 , respectively, both insignificant, in panel B). Also, banks with fewer female and minority directors have significantly higher All Concerns scores after the crisis, but not during and before (coefficient on $\%$ female \& minority directors is -1.285 , significant at $5 \%$, in panel C, and is -0.211 , insignificant, in panel B).

\section{1.b. Results Based on Bank Size}


Table 4 reports CSR regression results, separating the sample banks by size (for each quarter): total assets less than $\$ 10$ billion, between $\$ 10$ billion and $\$ 100$ billion, and greater than $\$ 100$ billion. Given the aggregation issues with the overall ESG Index, we look only at regressions using All Strengths or All Concerns as the dependent variable. Panel A reports results for the full sample period (2003-2011), panel B looks at the period before and during the worst of the financial crisis (2003-2009), and panel C reports results for 2010-2011 (as the worst of the financial crisis was over). Panel A establishes that several significant variables exist for the full sample period and differences in significant variables exist across size groups. However, we concentrate our discussion on results in panels B (for the period 2003-2009) and C (for the period 2010-2011). Notice first, that the largest banks find more and significantly stronger relations than smaller banks. This makes sense remembering that the biggest banks were hit hardest in the press with real and perceived violations of corporate social responsibility. Thus, it is this group of banks that have a bigger incentive to perform better along these lines. For this group, banks with the lowest fees to deposit ratios receive the highest All Strength scores before, during, and after the crisis (coefficient on high fees dummy variable is -2.740 , significant at $5 \%$ in panel B, and -1.444 and significant at 10\% in panel C). Banks with the lowest concentration of business in low income areas receive the highest All Concerns scores after the crisis (coefficient on percentage of low income counties served is -2.308 and significant at $10 \%$ ); the relation is insignificant before the crisis.

Table 5 reports results similar to those in Table 4, but uses only those banks for which we have corporate governance data. Results in Table 5 are generally consistent with those in Table 4. However, we now see that, regardless of bank size, before and during the financial crisis All Strengths scores are higher for banks with more female and minority directors (coefficient on \% 
female \& minority is 3.107 for banks with total assets less than $\$ 10$ billion, 3.467 for banks with total assets between $\$ 10$ billion and $\$ 100$ billion, and 10.244 for banks with total assets greater than $\$ 100$ billion). Further, regardless of bank size, after the worst of the financial crisis had passed All Concerns scores are lower for banks with more female and minority directors (the coefficient on \% female \& minority is -1.634 for banks with total assets less than $\$ 10$ billion, it is -1.533 for banks with total assets between $\$ 10$ billion and $\$ 100$ billion, and -8.122 for banks with total assets greater than $\$ 100$ billion).

\section{1.c. Results Based on Service to Low Income Communities}

Table 6 reports regression results highlighting the involvement of the sample banks in low income communities. Panel A reports results for banks with low involvement in low income communities, while panel B reports results for banks with relatively high involvement in low income communities. Notice for banks that have low involvement in low income communities, it is the smallest banks that show many significant relations between corporate social responsibility and bank characteristics. Yet for banks that have high involvement in low income communities, it is the largest banks that show many significant relations. In panel A, for banks with total assets less than $\$ 10$ billion, All Strengths scores are significantly higher for the largest banks in this group (coefficient is 0.256), banks with higher Tier 1 capital ratios (coefficient is 3.849), and during 2003-2009 (coefficient on post crisis dummy is -1.198). Similar relations are seen for

banks with total assets between $\$ 10$ billion and $\$ 100$ billion. However, for banks with total assets greater than $\$ 100$ billion, and relatively little involvement in low income communities, only size (coefficient is 5.601) and the post crisis dummy (coefficient is 5.348) are significantly related to All Strength scores. 
For banks with total assets less than $\$ 10$ billion, All Concerns scores are significantly higher for the lowest performing banks (coefficient on ROA industry adjusted is -2.806), banks with higher Tier 1 capital ratios (coefficient is 2.173), and during 2010-2011 (coefficient on post crisis dummy is 1.325). In contrast, for banks with total assets greater than $\$ 100$ billion, only size (coefficient is 3.658) is associated with higher All Concerns scores.

In contrast, for small banks with high involvement in low income areas, only the post crisis variable is significant: All Strengths scores are higher and All Concerns scores are lower in 2003-2009. For the largest banks with high involvement in low income areas, All Strengths scores increase with bank size (coefficient is 3.703), industry adjusted ROA (coefficient is 49.875), capital (coefficient is 24.026), lower fees (coefficient is -2.890), and after the worst of the financial crisis (coefficient is 1.876). All Concerns scores increase with bank size (coefficient is 2.772), lower fees (coefficient is -1.075), and before and during the financial crisis (coefficient is -1.376$)$.

Table 7 reports results similar to those in Table 6, but uses only those banks for which we have corporate governance data. Results in Table 7 are generally consistent with those in Table 6. For banks that have low involvement in low income communities, it is the smallest banks that show many significant relations between corporate social responsibility and bank characteristics. Yet for banks that have high involvement in low income communities, it is the largest banks that show many significant relations. We also see, however, that the percent of female and minority directors is positively related to All Strengths in banks that have relatively small concentration in low income communities (particularly for the smallest groups of banks (coefficients are 3.023 and 4.169, respectively)). Female and minority board members also have a positive effect on All 
Strengths scores for banks with relatively high concentration in low income communities (particularly for smallest and biggest banks (coefficients are 1.953 and 6.399, respectively)).

\subsection{Financial Performance Regressions}

Table 8 reports results of IV-GMM regressions examining the determinants of bank financial performance. Since we find that board composition matters for CSR, we base these regressions on a sample with governance variables. The post crisis dummy, log total assets, Tier 1 capital ratio, high fees dummy, percentage of low income counties served, percentage of independent directors, CEO-Chair duality, median tenure of board members, as well as percentage of female and minority directors are used as instruments for the CSR variable in each of the IV-GMM regressions. Since OLS results were similar, we only report IV-GMM results for brevity.

Panel A reports results for banks with total assets less than $\$ 10$ billion, panel B looks at banks with total assets between $\$ 10$ billion and $\$ 100$ billion, and panel C reports results for banks with total assets greater than $\$ 100$ billion. In each panel, regressions 1 -3 (4-6) employ industry adjusted ROA (ROE) as the measure of performance. Regressions 1 and 4 employ the overall ESG Index as the measure of CSR, regressions 2 and 5 the All Strengths score, and regressions 3 and 6 the All Concerns score. We find that CSR scores do not appear to affect bank performance (measured by industry adjusted ROA and ROE) for all the smallest size groups (panels A and B). However, for the largest banks, panel C reports that high overall CSR scores and high All Strengths are positively and significantly related to bank financial performance (coefficient on ESG Index (All Strengths) is 0.0002 (0.0001) in regression 1 (regression 2) and $0.002(0.001)$ in regression 4, both significant at $1 \%(5 \%))$. 
The Angrist-Pischke F-statistic from the first stage is always significant, indicating that our instruments are jointly significant, satisfying the relevancy criteria (which requires that the excluded instruments are sufficiently correlated with the included endogenous regressors). As for the Hansen-J test of overidentifying restrictions (which tests whether the excluded instruments are appropriately independent of the error process), we fail to reject the null hypothesis, indicating that our instruments satisfy the validity criteria, and that IV-GMM results are preferred to OLS results. Therefore, we can conclude that the overall ESG Index, as well as the All Strengths components, do affect bank performance (for the biggest banks). That is, banks that pursue CSR are, indeed, rewarded for these social activities with increased financial performance.

\subsection{Robustness Tests}

Servaes and Tamayo (2013) argue that corporate governance should not be considered as part of CSR, and therefore exclude the corporate governance scores from their construction of CSR strengths and concerns. As they state, "corporate governance is about the mechanisms that allow the principals (shareholders) to reward and exert control on the agents (the managers)...CSR, on the other hand, deals with social objectives and stakeholders other than shareholders. Hence, we leave corporate governance out of our CSR measure.” To ensure that our results are not being overly influenced by the inclusion of the corporate governance variables in our CSR scores, we rerun the performance regressions, excluding these variables from the ESG Index, All Strengths, and All Concerns scores. The results are reported in Table 9. Similar to Servaes and Tamayo (2013), we also scale the strengths and concerns for each firm-year by the maximum possible strengths and concerns in each category-year, since number of possible strengths and concerns varies from year to year. We again find that adjusted CSR scores (ones 
that exclude corporate governance variables and scaled by the maximum possible score each year) do not appear to affect bank performance (measured by industry adjusted ROA and ROE) for all the smallest size groups (panels A and B). However, for the largest banks, panel C reports that high overall CSR scores and high All Strengths are positively and significantly related to bank financial performance (coefficient on ESG Index (All Strengths) is 0.008 (0.003) in regression 1 (regression 2) and 0.077 (0.035) in regression 4).

Finally, over the period of analysis, the composition of the ESG indicators has been changing constantly. While we have 56 indicators from MSCI ESG STATS database at the end of our 2003-2011 period, some ratings have been added and some ratings have been discontinued, which results in 45 indicators being used in all years. In particular, there have been one new rating initiation in 2003, five in 2005, one in 2006, two in 2007, and seven in 2010. In addition, there have been two rating discontinuations in 2004, one in 2007, and 28 in 2009. While scaling by the maximum possible strength and concern scores as in Servaes and Tamayo (2013) mitigates this concern somewhat, we can further check the robustness of our results using the ratings that have been used consistently in our sample period.

To confirm that our results are not affected by the changing nature of the rating indicators, we rerun the performance regressions, including only the 45 indicators that have been consistently used in the MSCI ESG STATS database for the 2003-2011 period. The results are reported in Table 10 and are very similar to those in Tables 8 and 9. We find that CSR scores are not related to bank performance (measured by industry adjusted ROA and ROE) for all the smallest size groups (panels A and B). Still, for the largest banks, panel C reports that high overall CSR scores and high All Strengths are positively and significantly related to bank 
financial performance (coefficient on ESG Index (All Strengths) is 0.0002 (0.0001) in regression 1 (regression 2) and 0.002 (0.002) in regression 4).

\section{Conclusions}

This paper analyzes banks' social performance and its impact on bank financial performance in a context of the recent financial crisis. We use environmental, social, and governance scores from MSCI ESG STATS database over 2003-2011. MSCI ESG STATS evaluates companies on more than 50 indicators to capture "strengths" and "concerns" attributes in seven categories that include community, diversity, employee relations, environment, human rights, products and governance. We construct a variable All Strengths as the sum of all ESG scores on attributes that are identified as strengths and All Concerns in an analogous manner.

The largest banks consistently have higher All Strengths and All Concerns scores during the sample period. However, this group sees a steep increase in All Strengths and a steep drop in All Concerns after 2009, as the worst of the financial crisis passed. We also find that more profitable banks, banks with higher capital ratios, and banks that have charge lower fees to deposits have significantly higher All Strengths scores. Further, All Strengths scores decrease significantly for the full sample of banks in 2010-2011. We find that banks with more female and minority directors have significantly higher All Strengths scores. For banks that have low involvement in low income communities, it is the smallest banks that show many significant relations between corporate social responsibility and bank characteristics. Yet for banks that have high involvement in low income communities, it is the largest banks that show many significant relations. Finally, we find that the largest banks appear to be rewarded for being social responsibility, as both industry adjusted ROA and ROE are positively and significantly related to CSR scores. 


\section{References:}

Aktas, N., E. de Bodt, and J. Cousin, 2011. Do financial markets care about SRI? Evidence from mergers and acquisitions. Journal of Banking and Finance 35 (7) 1753-1761.

Albuquerque, R.A., A. Durnev, and Y. Koskinen, 2013. Corporate social responsibility and firm risk: Theory and empirical evidence. SSRN working paper: http://ssrn.com/abstract=1961971.

Bae, K., J. Kang, and J. Wang, 2011. Employee treatment and firm leverage: A test of the stakeholder theory of capital structure. Journal of Financial Economics 100(1), 130-153.

Bénabou, R., and J. Tirole, 2010. Individual and corporate social responsibility. Economica 77, 1-19.

Bouslah, K., L. Kryzanowski and B. M'Zali, 2013. The impact of the dimensions of social performance on firm risk. Journal of Banking and Finance 37 (4) 1258-1273.

Cheng, I., H. Hong, and K. Shue, 2013. Do managers do good with other people's money? SSRN working paper: http://ssrn.com/abstract=1962120.

Chih, H., H. Chih, and T. Chen, 2010. On the determinants of corporate social responsibility: International evidence on the financial industry. Journal of Business Ethics 93, 115-135.

Cowen, S. S., L. B. Ferreri and L. D. Parker, 1987. The impact of corporate characteristics on social responsibility disclosure: A typology and frequency-based analysis. Accounting, Organizations and Society 12 (2), 111-122.

Dimson, E. O. Karakaş, and X. Li, 2012. Active ownership. SSRN working paper: http://ssrn.com/abstract=2154724.

Edmans, A., 2011. Does the stock market fully value intangibles? Employee satisfaction and equity prices. Journal of Financial Economics 101 (3), 621-640.

El Ghoul, S., O. Guedhami, C. Kwok and D. Mishra, 2011. Does corporate social responsibility affect the cost of capital? Journal of Banking and Finance 35, 2388-2408.

Erhemjamts, O., Q. Li, and A. Venkateswaran, 2012. Corporate social responsibility and its impact on firms' investment policy, organizational strategy, and performance. Journal of Business Ethics, forthcoming.

Fich, E., D. Garcia, T. Robinson, and A. Yore, 2009. Corporate philanthropy, agency problems, and shareholder wealth. Working paper.

Galema, R., A. Plantinga, and B. Scholtens, 2008. The stocks at stake: Return and risk in socially responsible investment. Journal of Banking and Finance 32 (12), 2646-2654. 
Garcia-Castro, R., M. A. Ariño and M. A. Canela, 2010. Does social performance really lead to financial performance? Accounting for endogeneity. Journal of Business Ethics 92 (1), 107126.

Gillan, S.L., J.C. Hartzell, A. Koch, and L.T. Starks, 2010. Firms’ environmental, social and governance (ESG) choices, performance and managerial motivation. Working paper: University of Texas at Austin.

Goss, A., and G.S. Roberts, 2011. The impact of corporate social responsibility on the cost of bank loans. Journal of Banking and Finance 35 (7), 1794-1810.

Griffin, J. J. and J. F. Mahon, 1997. The corporate social performance and corporate financial performance debate. Business \& Society 36(1), 5-31.

Hayashi, F., 2000. Econometrics, Princeton University Press.

Heinkel, R., A. Kraus, and J. Zechner, 2001. The Effect of Green Investment on Corporate Behavior. Journal of Financial and Quantitative Analysis 36 (4), 431-449.

Hillman, A. J. and G. D. Keim, 2001. Shareholder value, stakeholder management, and social issues: What's the bottom line? Strategic Management Journal 22 (2), 125-139.

Hong, H., and M. Kacperczyk, 2009. The price of sin: The effects of social norms on markets. Journal of Financial Economics 93 (1), 15-36.

Hong, H., and L. Kostovetsky, 2011. Red and blue investing: Values and finance. Journal of Financial Economics 103 (1), 1-19.

Jiao, Y., 2010. Stakeholder welfare and firm value. Journal of Banking and Finance 34 (10), 2549-2561.

Margolis, J. D. and J. P. Walsh, 2003. Misery loves companies: Rethinking social initiatives by business. Administrative Science Quarterly 48 (2), 268-305.

Masulis, R.W., and S.W. Reza, 2013. Agency problems of corporate philanthropy. SSRN working paper: http://ssrn.com/abstract=2234221.

McWilliams, A., and D. Siegel, 2001. Corporate social responsibility: A theory of the firm perspective. Academy of Management Review 26, 117-127.

Petersen, M. A., 2009. Estimating standard errors in finance panel data sets: Comparing approaches. Review of Financial Studies 22 (1): 435-480.

Servaes, H., and A. Tamayo, 2013. The impact of corporate social responsibility on firm value: The role of customer awareness. Management Science 59 (5), 1045-1061.

Udayasankar, K., 2008. Corporate social responsibility and firm size. Journal of Business Ethics 83, 167-175. 
Waddock, S. A., and S. B. Graves, 1997. The corporate social performance-financial performance link. Strategic Management Journal 18 (4), 303-319.

Wang, J. and B. S. Coffey, 1992. Board composition and corporate philanthropy. Journal of Business Ethics 11 (10), 771-778.

White, H., 1980. A heteroskedasticity-consistent covariance matrix estimator and a direct test for heteroskedasticity. Econometrica 48, 817-38.

Wu, M., and C. Shen, 2013. Corporate social responsibility in the banking industry: Motives and financial performance. Journal of Banking and Finance 37, 3529-3547. 
Figure 1

\section{ESG Strength and Concern Scores by Size Group}

This figure shows a time series of ESG ratings for a sample of banks from 2003 through 2011. Panel A reports All Strengths measured as the sum of all ESG scores on attributes that are identified as strengths. Panel B reports All Concerns measured as the sum of all ESG scores on attributes that are identified as concerns. Ratings are reported by three size groups: banks with total assets less than $\$ 10$ billion, banks with total assets between $\$ 10$ billion and $\$ 100$ billion, and banks with total assets greater than $\$ 100$ billion.

\section{Panel A: ESG All Strength Scores}

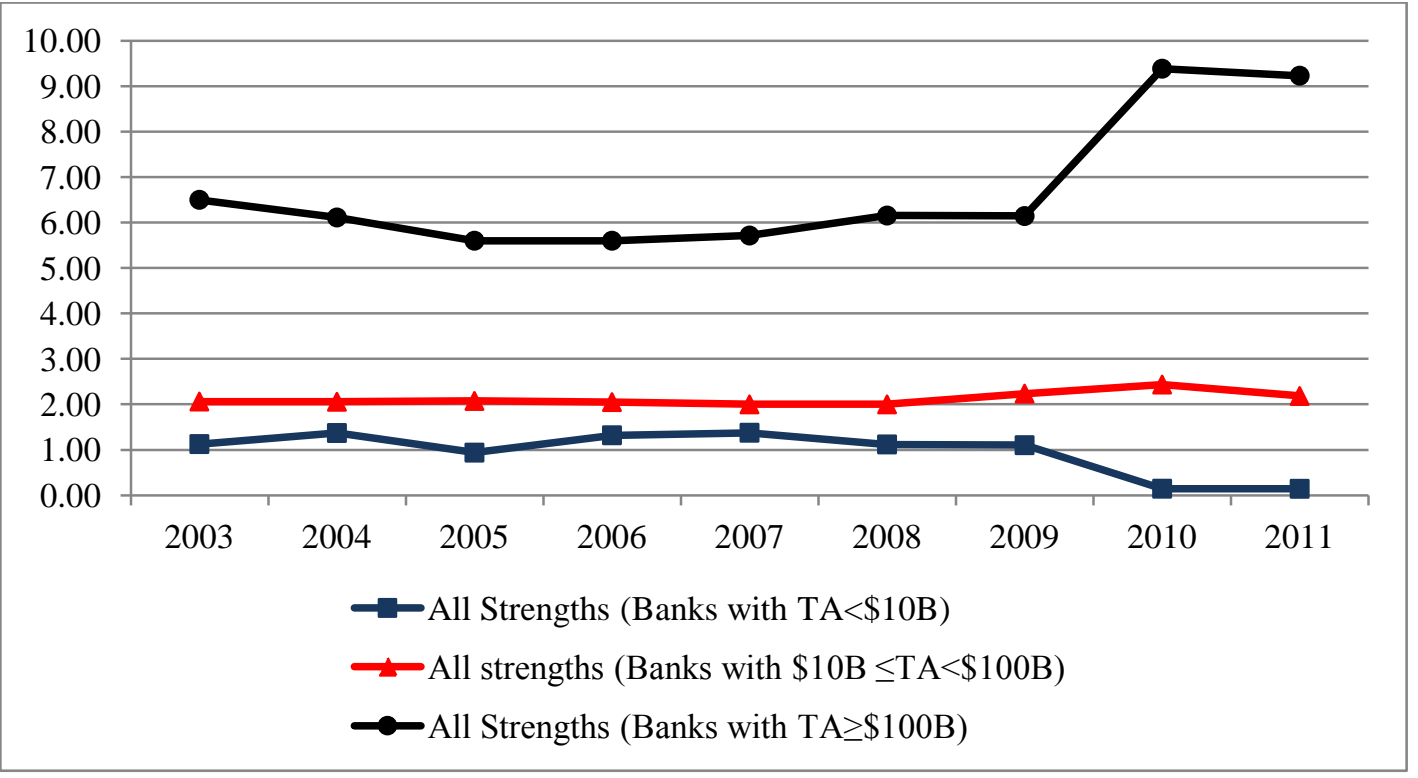

Panel B: ESG All Concerns Scores

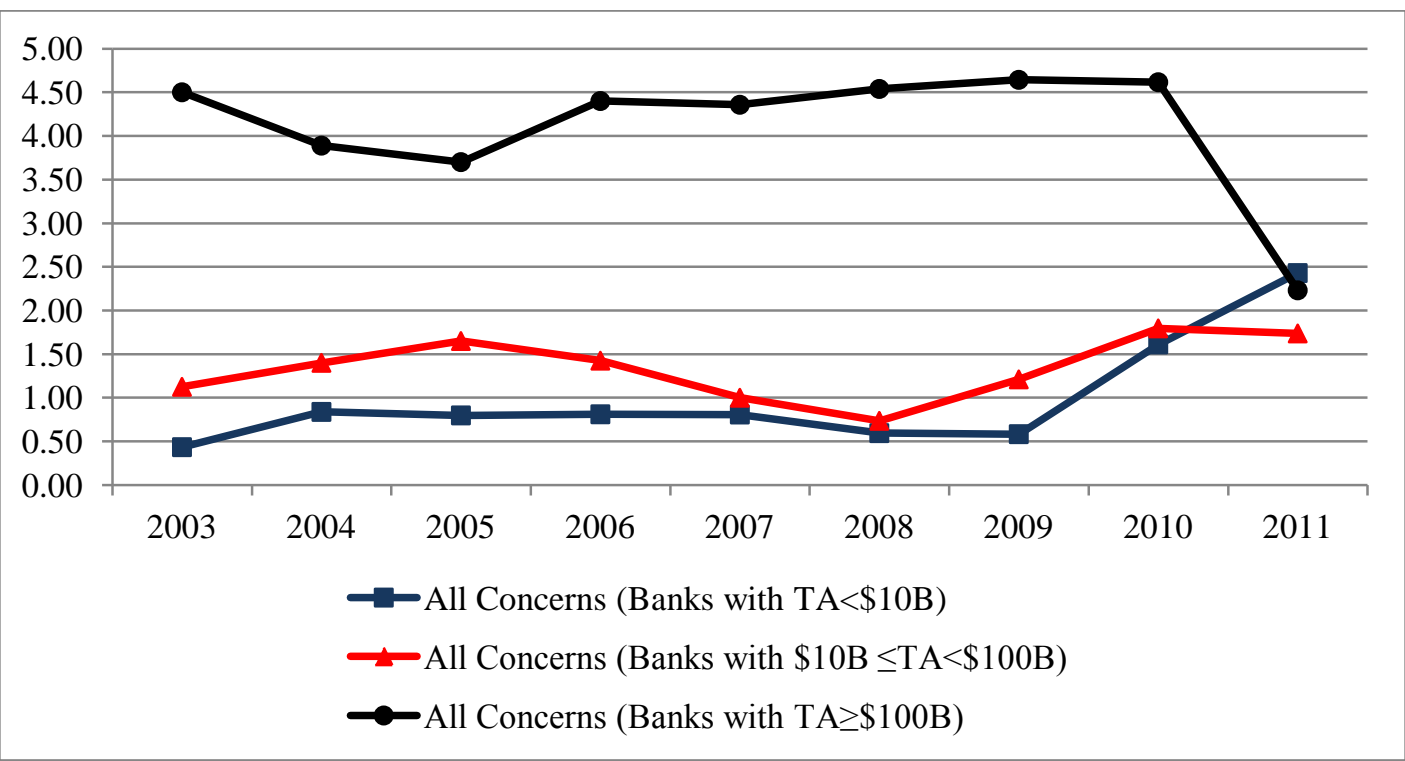


Figure 2

\section{Financial Performance by Size Group}

This figure shows a time series of industry adjusted ROA and ROE for a sample of banks from 2003 through 2011. Industry adjusted ROA and ROE is reported by three size groups: banks with total assets less than $\$ 10$ billion, banks with total assets between $\$ 10$ billion and $\$ 100$ billion, and banks with total assets greater than $\$ 100$ billion.

Panel A: Industry adjusted ROA

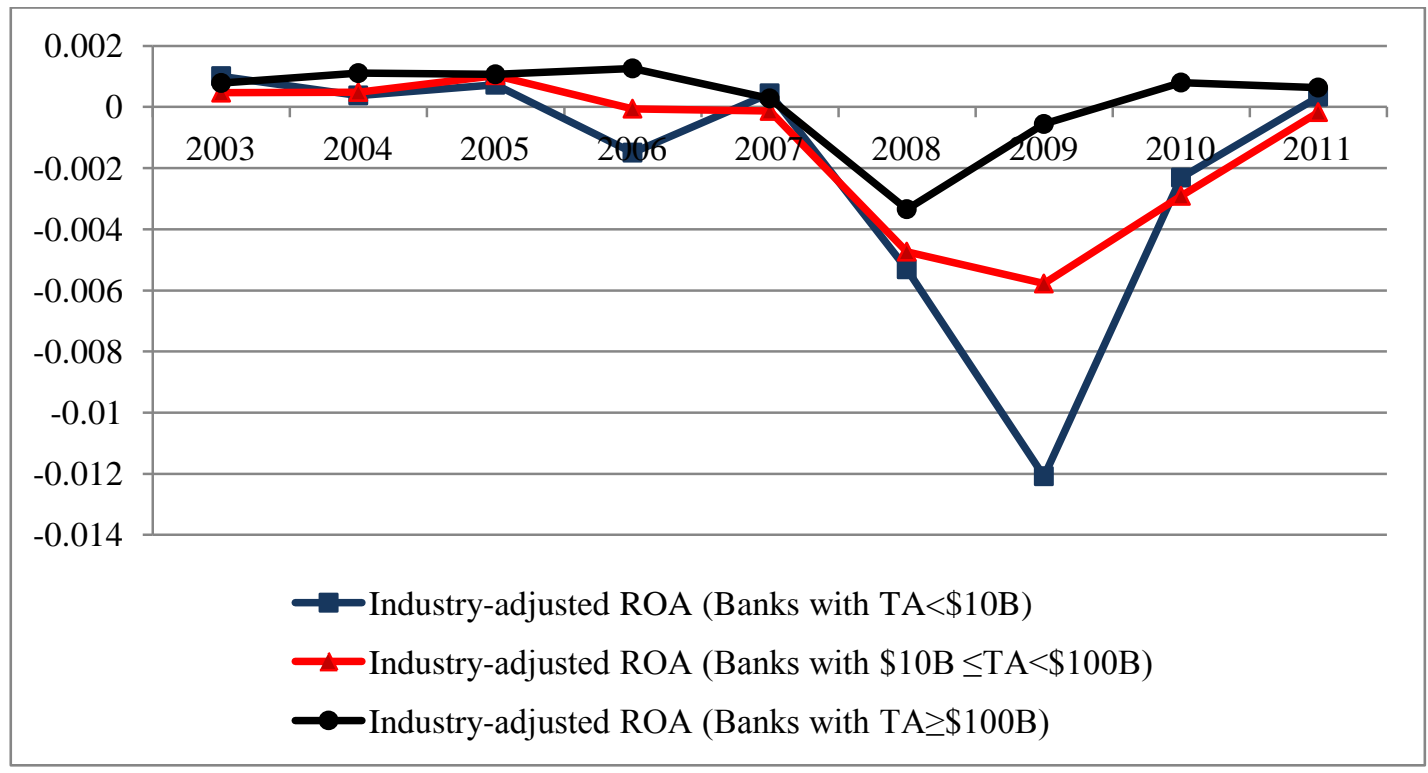

Panel B: Industry adjusted ROE

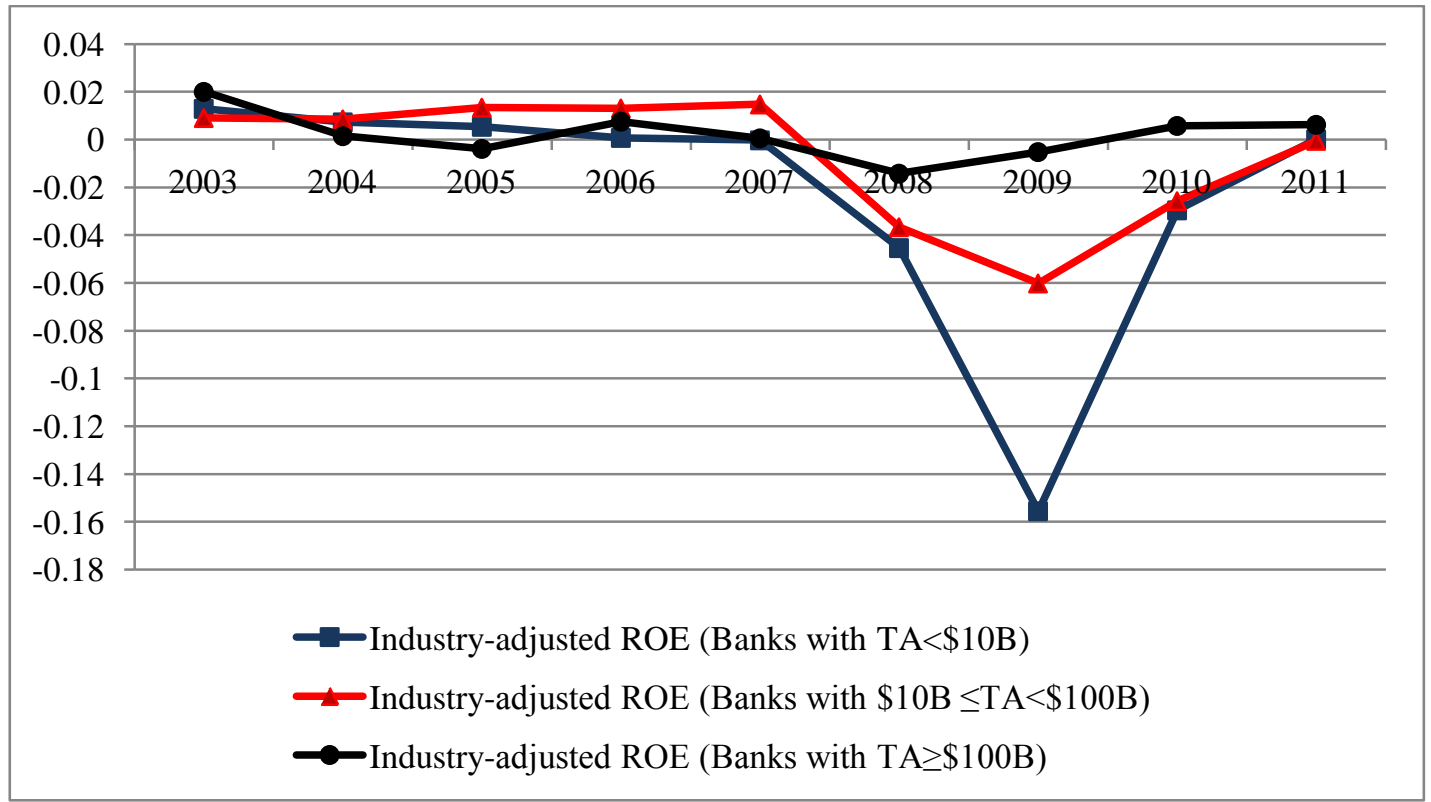




\section{Table 1}

\section{Descriptive Statistics on ESG Ratings Data}

This table reports components of MSCI ESG STATS All Strengths and All Concerns for a sample of banks from 2003 through 2011. If a company does meet the criteria established for a rating, this is indicated with a "1." If a company does not meet the criteria established for a rating, this is indicated with a " 0 ." These values are then summed across each category on strength and concern attributes. We construct a variable All Strengths as the sum of all ESG scores on attributes that are identified as strengths, and construct All Concerns in an analogous manner. Ratings are reported by three size groups: banks with total assets less than $\$ 10$ billion, banks with total assets between $\$ 10$ billion and $\$ 100$ billion, and anks with total assets greater than $\$ 100$ billion.

\begin{tabular}{|c|c|c|c|c|c|c|c|c|c|}
\hline \multirow[b]{2}{*}{ ESG Variable } & \multicolumn{3}{|c|}{ Banks with $\mathrm{TA}<\$ 10 \mathrm{~B}$} & \multicolumn{3}{|c|}{ Banks with $\$ 10 \mathrm{~B} \leq \mathrm{TA}<\$ 100 \mathrm{~B}$} & \multicolumn{3}{|c|}{ Banks with $\mathrm{TA} \geq \$ 100 \mathrm{~B}$} \\
\hline & $\begin{array}{c}2003- \\
2009 \\
\end{array}$ & $\begin{array}{l}2010- \\
2011 \\
\end{array}$ & t-test & $\begin{array}{c}2003- \\
2009 \\
\end{array}$ & $\begin{array}{c}2010- \\
2011 \\
\end{array}$ & t-test & $\begin{array}{c}2003- \\
2009\end{array}$ & $\begin{array}{c}2010- \\
2011\end{array}$ & t-test \\
\hline ESG Index & 0.49 & -1.86 & $* * *$ & 0.83 & 0.55 & & 1.64 & 5.88 & $* * *$ \\
\hline All Strengths & 1.19 & 0.14 & $* * *$ & 2.07 & 2.31 & & 5.96 & 9.31 & $* * *$ \\
\hline Community Strengths & 0.23 & 0.02 & $* * *$ & 0.45 & 0.23 & $* * *$ & 1.87 & 0.77 & $* * *$ \\
\hline Environment Strengths & 0.00 & 0.02 & $* *$ & 0.00 & 0.53 & $* * *$ & 0.12 & 2.38 & $* * *$ \\
\hline Diversity Strengths & 0.35 & 0.09 & $* * *$ & 1.00 & 0.92 & & 2.76 & 4.23 & $* * *$ \\
\hline Emp. Relations Strengths & 0.07 & 0.00 & $* * *$ & 0.38 & 0.26 & & 0.77 & 0.46 & $*$ \\
\hline Human Rights Strengths & 0.00 & 0.00 & & 0.00 & 0.01 & $*$ & 0.09 & 0.23 & $*$ \\
\hline Product Strengths & 0.00 & 0.02 & $* * *$ & 0.01 & 0.26 & $* * *$ & 0.08 & 0.77 & $* * *$ \\
\hline Corp. Gov. Strengths & 0.53 & 0.00 & $* * *$ & 0.23 & 0.09 & $* * *$ & 0.28 & 0.46 & $*$ \\
\hline All Concerns & 0.69 & 2.00 & $* * *$ & 1.24 & 1.77 & $* * *$ & 4.32 & 3.42 & \\
\hline Community Concerns & 0.14 & 0.00 & $* * *$ & 0.20 & 0.00 & $* * *$ & 0.55 & 0.12 & $* * *$ \\
\hline Environment Concerns & 0.00 & 0.00 & & 0.00 & 0.05 & $* *$ & 0.00 & 0.31 & $* * *$ \\
\hline Diversity Concerns & 0.29 & 1.36 & $* * *$ & 0.13 & 0.58 & $* * *$ & 0.38 & 0.38 & \\
\hline Emp. Relations Concerns & 0.15 & 0.00 & $* * *$ & 0.26 & 0.08 & $* * *$ & 0.44 & 0.35 & \\
\hline Human Rights Concerns & 0.00 & 0.00 & & 0.01 & 0.03 & & 0.24 & 0.08 & $*$ \\
\hline Product Concerns & 0.05 & 0.04 & & 0.24 & 0.30 & & 1.55 & 1.35 & \\
\hline Corp. Gov. Concerns & 0.06 & 0.59 & $* * *$ & 0.40 & 0.73 & $* * *$ & 1.15 & 0.85 & \\
\hline Firm-year Observations & 1031 & 250 & & 250 & 77 & & 78 & 26 & \\
\hline
\end{tabular}




\section{Table 2}

\section{Descriptive Statistics on Bank Corporate Social Responsibility, Performance, and Governance}

This table reports descriptive statistics for variables used to analyze a sample of 190 banks from 2003 through 2011 . We first collect environmental, social, and governance (ESG) ratings of largest 3,000 publicly traded companies from MSCI ESG STATS. We then merge the ESG ratings data for financial institutions with the Call Reports database from FFIEC. Eliminating banks with only one year of ESG rating observation results in 1,712 bank-year observations with an average of 190 banks per year. Measures of board composition are collected from RiskMetrics Directors database, supplemented with data collected from proxy statements when RiskMetrics data were not available.

\begin{tabular}{|c|c|c|c|c|c|c|}
\hline Variable & $\mathbf{N}$ & Mean & Median & Minimum & Maximum & Std. Dev. \\
\hline All Strengths & 1,712 & 1.56 & 1.00 & 0.00 & 15.00 & 2.26 \\
\hline All Concerns & 1,712 & 1.22 & 1.00 & 0.00 & 11.00 & 1.53 \\
\hline Total Assets ( $\$$ billions) & 1,712 & 38.89 & 3.53 & 0.12 & $1,930.83$ & 177.35 \\
\hline ROA Industry Adjusted & 1,712 & $-0.16 \%$ & $0.07 \%$ & $-36.11 \%$ & $5.50 \%$ & $1.54 \%$ \\
\hline Tier 1 Capital Ratio & 1,712 & $11.51 \%$ & $10.71 \%$ & $3.51 \%$ & $61.58 \%$ & $3.85 \%$ \\
\hline Fees to Deposits & 1,712 & $0.53 \%$ & $0.47 \%$ & $0.00 \%$ & $3.67 \%$ & $0.36 \%$ \\
\hline \% Low Income Counties & 1,712 & $41.93 \%$ & $40.00 \%$ & $0.00 \%$ & $100.00 \%$ & $26.73 \%$ \\
\hline \multicolumn{7}{|c|}{ Panel B: Subsample with Governance Variables } \\
\hline Variable & $\mathbf{N}$ & Mean & Median & Minimum & Maximum & Std. Dev. \\
\hline All Strengths & 918 & 2.08 & 1.00 & 0.00 & 15.00 & 2.80 \\
\hline All Concerns & 918 & 1.47 & 1.00 & 0.00 & 11.00 & 1.83 \\
\hline Total Assets ( $\$$ billions) & 918 & 68.71 & 7.41 & 0.28 & 1930.83 & 237.84 \\
\hline ROA Industry Adjusted & 918 & $-0.16 \%$ & $0.07 \%$ & $-36.11 \%$ & $4.73 \%$ & $1.74 \%$ \\
\hline Tier 1 Capital Ratio & 918 & $11.59 \%$ & $10.69 \%$ & $3.51 \%$ & $61.58 \%$ & $4.40 \%$ \\
\hline Fees to Deposits & 918 & $0.57 \%$ & $0.54 \%$ & $0.00 \%$ & $3.67 \%$ & $0.41 \%$ \\
\hline \% Low Income Counties & 918 & $43.23 \%$ & $43.48 \%$ & $0.00 \%$ & $100.00 \%$ & $24.42 \%$ \\
\hline \% Indep. Directors & 918 & $74.87 \%$ & $77.35 \%$ & $27.27 \%$ & $100.00 \%$ & $12.71 \%$ \\
\hline CEO-Chair Duality & 918 & $55.45 \%$ & $100.00 \%$ & $0.00 \%$ & $100.00 \%$ & $49.73 \%$ \\
\hline \% Fem \& Minority Dir's & 918 & $17.23 \%$ & $14.29 \%$ & $0.00 \%$ & $122.22 \%$ & $15.96 \%$ \\
\hline Median Tenure Dir's & 918 & 9.39 & 9.00 & 2.00 & 26.00 & 4.11 \\
\hline
\end{tabular}




\section{Table 3}

\section{Corporate Social Responsibility Regressions}

This table reports OLS regression results in which we examine determinants of Corporate Social Responsibility ESG ratings. Panel A includes the entire sample period (2003-2011), panel B examines years before and at the start of the financial crisis (2003-2009), and panel C includes the period 2010-2011. We collect environmental, social, and governance (ESG) ratings of largest 3,000 publicly traded companies from MSCI ESG STATS. We then merge the ESG ratings data for financial institutions with the Consolidated Report of Condition and Income (i.e., Call Reports) database from Federal Financial Institutions Examination Council (FFIEC). This combined dataset is the base for all our analyses. Eliminating banks with only one year of ESG rating observation results in 1,712 bank-year observations with an average of 190 banks per year. Measures of board composition are collected from RiskMetrics Directors database, supplemented with data collected from proxy statements when RiskMetrics data were not available. ${ }^{* * *} \mathrm{p}<0.01,{ }^{* *} \mathrm{p}<0.05,{ }^{*} \mathrm{p}<0.10$.

\begin{tabular}{|c|c|c|c|c|c|c|}
\hline \multicolumn{7}{|c|}{ Panel A: All Years } \\
\hline & (1) & (2) & (3) & (4) & (5) & (6) \\
\hline & ESG Index & All Strengths & All Concerns & ESG Index & All Strengths & All Concerns \\
\hline Log Total Assets & $-2.197 *$ & $-7.568 * * *$ & $-5.371^{* * *}$ & -1.522 & $-8.158^{* * *}$ & $-6.636 * * *$ \\
\hline Log Total Assets Squared & $0.081 * *$ & $0.259 * * *$ & $0.178 * * *$ & 0.057 & $0.273^{* * *}$ & $0.215^{* * * *}$ \\
\hline ROA Industry Adjusted & $5.706^{*}$ & $7.005^{* *}$ & 1.299 & $9.811^{* *}$ & $12.935^{* *}$ & 3.124 \\
\hline Tier 1 Capital Ratio & $2.503 *$ & $5.511^{* * *}$ & $3.008 * * *$ & 3.490 & $6.417 * *$ & $2.927^{*}$ \\
\hline High Fees Dummy & -0.149 & $-0.321 * *$ & $-0.172 *$ & 0.056 & -0.270 & $-0.325^{* *}$ \\
\hline \% Low Income Counties & -0.024 & 0.083 & 0.106 & 0.431 & 0.094 & -0.337 \\
\hline Post Crisis Dummy & $-1.575^{* * *}$ & $-0.728 * * *$ & $0.847 * * *$ & $-1.016 * * *$ & $-0.545^{* * *}$ & $0.471^{* * *}$ \\
\hline \% Independent Directors & & & & 0.540 & 0.304 & -0.236 \\
\hline \% Female \& Minority Directors & & & & $3.768 * * *$ & $3.178^{* * *}$ & $-0.591^{*}$ \\
\hline CEO-Chair Duality & & & & -0.041 & 0.037 & 0.078 \\
\hline Director Tenure & & & & -0.019 & -0.025 & -0.006 \\
\hline Constant & 14.812 & $55.675 * * *$ & $40.863^{* * *}$ & 8.843 & $60.943^{* * *}$ & $52.100 * * *$ \\
\hline Adjusted R-Squared & 0.22 & 0.58 & 0.48 & 0.25 & 0.64 & 0.53 \\
\hline N & 1712 & 1712 & 1712 & 918 & 918 & 918 \\
\hline
\end{tabular}


Panel B: 2003-2009

\begin{tabular}{|c|c|c|c|c|c|c|}
\hline & $\begin{array}{c}(1) \\
\text { ESG Index }\end{array}$ & $\begin{array}{c}\text { (2) } \\
\text { All Strengths } \\
\end{array}$ & $\begin{array}{c}\text { (3) } \\
\text { All Concerns } \\
\end{array}$ & $\begin{array}{c}(4) \\
\text { ESG Index }\end{array}$ & $\begin{array}{c}\text { (5) } \\
\text { All Strengths }\end{array}$ & $\begin{array}{c}(6) \\
\text { All Concerns } \\
\end{array}$ \\
\hline Log Total Assets & -1.567 & $-7.091^{* * *}$ & $-5.524 * * *$ & -0.765 & $-7.931 * * *$ & $-7.166 * * *$ \\
\hline Log Total Assets Squared & 0.054 & $0.239 * * *$ & $0.186 * * *$ & 0.027 & $0.260 * * *$ & $0.233^{* * *}$ \\
\hline ROA Industry Adjusted & 4.461 & $5.117 *$ & 0.656 & 4.923 & 7.566 & 2.643 \\
\hline Tier 1 Capital Ratio & -0.389 & 3.129 & $3.518^{* *}$ & -1.677 & 2.238 & $3.915^{* *}$ \\
\hline High Fees Dummy & -0.128 & $-0.296 *$ & -0.168 & 0.147 & -0.206 & $-0.353 * *$ \\
\hline \% Low Income Counties & -0.144 & 0.055 & 0.198 & 0.502 & 0.119 & -0.383 \\
\hline \% Independent Directors & & & & -0.424 & -0.264 & 0.159 \\
\hline \% Female \& Minority Directors & & & & $4.131^{* * *}$ & $3.920 * * *$ & -0.211 \\
\hline CEO-Chair Duality & & & & -0.295 & -0.150 & 0.145 \\
\hline Director Tenure & & & & -0.002 & 0.003 & 0.005 \\
\hline Constant & 12.099 & $53.453 * * *$ & $41.354 * * *$ & 5.886 & $61.291 * * *$ & $55.405^{* * *}$ \\
\hline Adjusted R-Squared & 0.05 & 0.52 & 0.52 & 0.16 & 0.63 & 0.59 \\
\hline $\mathrm{N}$ & 1359 & 1359 & 1359 & 707 & 707 & 707 \\
\hline
\end{tabular}

\section{Panel C: 2010-2011}

\begin{tabular}{|c|c|c|c|c|c|c|}
\hline & $\begin{array}{c}\text { (1) } \\
\text { ESG Index }\end{array}$ & $\begin{array}{c}\text { (2) } \\
\text { All Strengths }\end{array}$ & $\begin{array}{c}\text { (3) } \\
\text { All Concerns }\end{array}$ & $\begin{array}{c}(4) \\
\text { ESG Index }\end{array}$ & $\begin{array}{c}\text { (5) } \\
\text { All Strengths }\end{array}$ & $\begin{array}{c}(6) \\
\text { All Concerns }\end{array}$ \\
\hline Log Total Assets & -2.178 & $-7.968 * * *$ & $-5.790 * * *$ & -0.777 & $-7.013 * * *$ & $-6.236 * * *$ \\
\hline Log Total Assets Squared & $0.108 * *$ & $0.288 * * *$ & $0.180^{* * *}$ & 0.062 & $0.256 * * *$ & $0.195 * * *$ \\
\hline ROA Industry Adjusted & 19.927 & 18.198 & -1.729 & 29.416 & $40.359 * *$ & $10.943^{*}$ \\
\hline Tier 1 Capital Ratio & $6.747 * *$ & $8.448 * * *$ & 1.701 & $11.992 * * *$ & $12.669 * * *$ & 0.677 \\
\hline High Fees Dummy & -0.528 & $-0.574^{*}$ & -0.046 & -0.654 & $-0.736 *$ & -0.082 \\
\hline$\%$ Low Income Counties & 0.115 & 0.004 & -0.111 & 0.301 & 0.158 & -0.143 \\
\hline \% Independent Directors & & & & $4.088 * * *$ & $2.585 *$ & $-1.503^{* *}$ \\
\hline \% Female \& Minority Directors & & & & $2.944 * *$ & 1.658 & $-1.285^{* *}$ \\
\hline CEO-Chair Duality & & & & 0.527 & 0.485 & -0.042 \\
\hline Director Tenure & & & & -0.007 & $-0.066^{*}$ & $-0.060 * * *$ \\
\hline Constant & 5.402 & $53.636 * * *$ & $48.234^{* * *}$ & -9.443 & $43.955 * * *$ & $53.398 * * *$ \\
\hline Adjusted R-Squared & 0.60 & 0.77 & 0.30 & 0.60 & 0.77 & 0.39 \\
\hline $\mathrm{N}$ & 353 & 353 & 353 & 211 & 211 & 211 \\
\hline
\end{tabular}




\section{Table 4}

\section{Corporate Social Responsibility Regressions by Size Group}

This table reports regression results in which we examine determinants of Corporate Social Responsibility ESG ratings by size of the sample banks. We examine the sample banks based on three size groups consistent with FDIC size groupings: total assets less than $\$ 10$ billion, total assets between $\$ 10$ billion and $\$ 100$ billion, and total assets greater than $\$ 100$ billion. Panel A includes the entire sample period (2003-2011), panel B examines years before and at the start of the financial crisis (2003-2009), and panel C includes the period 2010-2011. We collect environmental, social, and governance (ESG) ratings of largest 3,000 publicly traded companies from MSCI ESG STATS. We then merge the ESG ratings data for financial institutions with the Consolidated Report of Condition and Income (i.e., Call Reports) database from Federal Financial Institutions Examination Council (FFIEC). This combined dataset is the base for all our analyses. ${ }^{* * *} \mathrm{p}<0.01,{ }^{* *} \mathrm{p}<0.05,{ }^{*} \mathrm{p}<0.10$.

\section{Panel A: All Years}

\begin{tabular}{lllllll}
\hline & \multicolumn{2}{c}{ Banks with TA<\$10B } & \multicolumn{2}{c}{ Banks with $\$ 10 \mathrm{~B}<=\mathrm{TA}<\$ 100 \mathrm{~B}$} & \multicolumn{2}{c}{ Banks with TA $>=\$ 100 \mathrm{~B}$} \\
& All Strengths & All Concerns & All Strengths & All Concerns & All Strengths & All Concerns \\
\hline Log Total Assets & $0.173^{* *}$ & 0.035 & $1.839^{* * *}$ & $0.889^{* * *}$ & $3.681^{* * *}$ & $2.777^{* * *}$ \\
ROA Industry Adjusted & 1.337 & -0.896 & $33.275^{*}$ & 6.147 & $54.710^{* *}$ & 14.037 \\
Tier 1 Capital Ratio & $3.329^{* * *}$ & $2.287^{* * *}$ & $23.927^{* * *}$ & $15.697^{* *}$ & 21.065 & -0.198 \\
High Fees Dummy & -0.139 & -0.068 & -0.055 & -0.226 & $-2.631^{* * *}$ & $-1.024^{* * *}$ \\
\% Low Income Counties & -0.051 & 0.220 & -0.395 & -0.677 & 0.278 & -0.881 \\
Post Crisis Dummy & $-1.175^{* * *}$ & $1.235^{* * *}$ & -0.328 & 0.090 & $2.003^{* * *}$ & $-1.271^{* *}$ \\
Constant & -1.652 & -0.135 & $-31.231^{* * *}$ & $-14.981^{* * *}$ & $-65.908^{* * *}$ & $-48.702^{* * *}$ \\
\hline Adjusted R-Squared & 0.17 & 0.25 & 0.31 & 0.27 & 0.82 & 0.78 \\
$\mathrm{~N}$ & 1281 & 1281 & 327 & 327 & 104 & 104 \\
\hline
\end{tabular}


Panel B: 2003-2009

\begin{tabular}{lllllll}
\hline & \multicolumn{2}{c}{ Banks with TA<\$10B } & \multicolumn{2}{c}{ Banks with $\$ 10 \mathrm{~B}<=\mathrm{TA}<\$ 100 \mathrm{~B}$} & \multicolumn{2}{c}{ Banks with TA $>=\$ 100 \mathrm{~B}$} \\
& All Strengths & All Concerns & All Strengths & All Concerns & All Strengths & \multicolumn{1}{c}{ All Concerns } \\
\hline Log Total Assets & 0.172 & $0.168^{* *}$ & $1.364^{* * *}$ & $0.794^{* * *}$ & $3.873^{* * *}$ & $2.940^{* * *}$ \\
ROA Industry Adjusted & -0.036 & $-2.475^{*}$ & $36.092^{* *}$ & 6.971 & $46.571^{* *}$ & 24.751 \\
Tier 1 Capital Ratio & 1.122 & 2.249 & $15.488^{* *}$ & $15.510^{* * *}$ & 18.163 & -10.934 \\
High Fees Dummy & -0.182 & -0.042 & 0.176 & -0.253 & $-2.740^{* *}$ & $-1.603^{* *}$ \\
\% Low Income Counties & -0.019 & 0.314 & 0.240 & $-0.892^{* *}$ & -0.799 & -1.215 \\
Constant & -1.504 & $-2.330^{*}$ & $-23.013^{* * *}$ & $-13.474^{* * *}$ & $-68.591^{* * *}$ & $-50.835^{* * *}$ \\
\hline Adjusted R-Squared & 0.03 & 0.05 & 0.24 & 0.26 & 0.78 & 0.85 \\
$\mathrm{~N}$ & 1031 & 1031 & 250 & 250 & 78 & 78 \\
\hline
\end{tabular}

Panel C: 2010-2011

\begin{tabular}{lllllll}
\hline & \multicolumn{2}{c}{ Banks with TA<\$10B } & \multicolumn{2}{c}{ Banks with $\$ 10 \mathrm{~B}<=\mathrm{TA}<\$ 100 \mathrm{~B}$} & \multicolumn{2}{c}{ Banks with TA $>=\$ 100 \mathrm{~B}$} \\
& All Strengths & All Concerns & All Strengths & All Concerns & All Strengths & All Concerns \\
\hline Log Total Assets & 0.079 & $-0.530^{* * *}$ & $3.715^{* * *}$ & $1.205^{* *}$ & $3.355^{* * *}$ & $2.385^{* * *}$ \\
ROA Industry Adjusted & $-4.750^{* *}$ & -6.073 & 25.809 & -1.305 & $188.257^{* * *}$ & -37.706 \\
Tier 1 Capital Ratio & $5.941^{* * *}$ & 1.082 & $43.905^{* * *}$ & 14.155 & $48.606^{* *}$ & 21.125 \\
High Fees Dummy & -0.004 & 0.008 & -0.660 & -0.118 & $-1.444^{*}$ & 0.153 \\
\% Low Income Counties & 0.064 & 0.097 & -2.325 & -0.102 & 3.133 & $-2.308^{*}$ \\
Constant & $-1.926^{* * *}$ & $10.103^{* * *}$ & $-64.429 * * *$ & $-20.200^{* *}$ & $-63.671^{* * *}$ & $-46.238^{* * *}$ \\
\hline Adjusted R-Squared & 0.44 & 0.30 & 0.55 & 0.20 & 0.90 & 0.82 \\
$\mathrm{~N}$ & 250 & 250 & 77 & 77 & 26 & 26 \\
\hline
\end{tabular}




\section{Table 5}

\section{Corporate Social Responsibility Regressions by Size Group - Subsample with Governance Variables}

This table reports regression results in which we examine determinants of Corporate Social Responsibility ESG ratings by size of the sample banks. We examine the sample banks based on three size groups consistent with FDIC size groupings: total assets less than $\$ 10$ billion, total assets between $\$ 10$ billion and \$100 billion, and total assets greater than \$100 billion. Panel A includes the entire sample period (2003-2011), panel B examines years before and at the start of the financial crisis (2003-2009), and panel C includes the period 2010-2011. We collect environmental, social, and governance (ESG) ratings of largest 3,000 publicly traded companies from MSCI ESG STATS. We then merge the ESG ratings data for financial institutions with the Consolidated Report of Condition and Income (i.e., Call Reports) database from Federal Financial Institutions Examination Council (FFIEC). This combined dataset is the base for all our analyses. Measures of board composition are collected from RiskMetrics Directors database, supplemented with data collected from proxy statements when RiskMetrics data were not available. ${ }^{* * *} \mathrm{p}<0.01$, $* * \mathrm{p}<0.05, * \mathrm{p}<0.10$.

\section{Panel A: All Years}

\begin{tabular}{lllllll}
\hline & \multicolumn{2}{c}{ Banks with TA $<\$ 10 \mathrm{~B}$} & \multicolumn{2}{c}{ Banks with $\$ 10 \mathrm{~B}<=\mathrm{TA}<\$ 100 \mathrm{~B}$} & \multicolumn{2}{c}{ Banks with TA $>=\$ 100 \mathrm{~B}$} \\
& All Strengths & All Concerns & All Strengths & All Concerns & All Strengths & All Concerns \\
\hline Log Total Assets & $0.212^{* *}$ & 0.039 & $1.821^{* * *}$ & $0.893^{* * *}$ & $3.285^{* * *}$ & $2.836^{* * *}$ \\
ROA Industry Adjusted & 2.619 & -2.229 & $41.471^{* *}$ & 4.975 & $27.157^{*}$ & 22.181 \\
Tier 1 Capital Ratio & $3.720^{* * *}$ & $2.034^{* *}$ & $22.683^{* * *}$ & $19.331^{* * *}$ & 20.394 & -2.277 \\
High Fees Dummy & -0.053 & -0.103 & 0.153 & -0.282 & $-2.243^{* *}$ & $-1.336^{* * *}$ \\
\% Low Income Counties & -0.022 & -0.265 & -0.373 & -0.907 & 0.688 & -1.138 \\
\% Independent Directors & 0.450 & -0.225 & -0.173 & 0.145 & -2.119 & -0.457 \\
\% Female \& Minority Directors & $2.469^{* * *}$ & $-0.903^{*}$ & $2.921^{* * *}$ & -0.679 & $7.413^{* *}$ & -2.311 \\
CEO-Chair Duality & 0.105 & 0.164 & 0.216 & 0.202 & -0.335 & 0.352 \\
Director Tenure & 0.002 & 0.006 & -0.072 & -0.037 & 0.068 & -0.098 \\
Post Crisis Dummy & $-1.279^{* * *}$ & $0.887^{* * *}$ & -0.390 & 0.040 & $1.942^{* *}$ & $-1.183^{*}$ \\
Constant & $-2.964^{*}$ & 0.294 & $-30.827^{* * *}$ & $-15.060^{* * *}$ & $-59.270^{* * *}$ & $-47.719^{* * *}$ \\
\hline Adjusted R-Squared & 0.29 & 0.13 & 0.37 & 0.28 & 0.85 & 0.79 \\
$\mathrm{~N}$ & 528 & 528 & 291 & 291 & 99 & 99 \\
\hline
\end{tabular}


Panel B: 2003-2009

\begin{tabular}{lllllll}
\hline & \multicolumn{2}{c}{ Banks with TA<\$10B } & \multicolumn{2}{c}{ Banks with $\$ 10 \mathrm{~B}<=\mathrm{TA}<\$ 100 \mathrm{~B}$} & \multicolumn{2}{c}{ Banks with TA $>=\$ 100 \mathrm{~B}$} \\
& All Strengths & All Concerns & All Strengths & All Concerns & All Strengths & All Concerns \\
\hline Log Total Assets & 0.211 & 0.179 & $1.360^{* * *}$ & $0.826^{* * *}$ & $3.223^{* * *}$ & $2.999^{* * *}$ \\
ROA Industry Adjusted & -1.200 & -3.563 & $40.316^{* *}$ & 5.599 & 7.712 & 30.567 \\
Tier 1 Capital Ratio & 0.368 & 2.448 & $12.473^{*}$ & $19.829^{* * *}$ & 34.048 & -15.720 \\
High Fees Dummy & -0.113 & -0.086 & 0.393 & -0.278 & -1.551 & $-2.123^{* * *}$ \\
\% Low Income Counties & 0.154 & -0.298 & 0.243 & $-1.253^{* *}$ & -2.405 & -2.388 \\
\% Independent Directors & 0.633 & -0.015 & -1.447 & 0.436 & -3.089 & -1.985 \\
\% Female \& Minority Directors & $3.107^{* * *}$ & -0.748 & $3.467^{* * *}$ & 0.026 & $10.244^{* *}$ & -2.060 \\
CEO-Chair Duality & 0.095 & 0.185 & -0.200 & 0.263 & -0.100 & $0.805^{*}$ \\
Director Tenure & 0.002 & 0.017 & -0.022 & -0.021 & 0.005 & $-0.135^{* *}$ \\
Constant & -2.643 & -2.387 & $-21.936^{* * *}$ & $-14.605^{* * *}$ & $-57.717^{* * *}$ & $-47.582^{* * *}$ \\
\hline Adjusted R-Squared & 0.17 & 0.03 & 0.30 & 0.28 & 0.84 & 0.87 \\
$\mathrm{~N}$ & 415 & 415 & 217 & 217 & 75 & 75 \\
\hline
\end{tabular}

\section{Panel C: 2010-2011}

\begin{tabular}{|c|c|c|c|c|c|c|}
\hline & \multicolumn{2}{|c|}{ Banks with TA $<\$ 10 B$} & \multicolumn{2}{|c|}{ Banks with $\$ 10 \mathrm{~B}<=\mathrm{TA}<\$ 100 \mathrm{~B}$} & \multicolumn{2}{|c|}{ Banks with TA $>=\$ 100 \mathrm{~B}$} \\
\hline & All Strengths & All Concerns & All Strengths & All Concerns & All Strengths & All Concerns \\
\hline Log Total Assets & 0.121 & $-0.751 * * *$ & $3.063 * * *$ & $1.271 * *$ & $3.206 * * *$ & $2.502 * * *$ \\
\hline ROA Industry Adjusted & -2.538 & -1.776 & 24.974 & -0.561 & $227.716 * * *$ & -17.181 \\
\hline Tier 1 Capital Ratio & $7.541^{* * *}$ & -1.487 & $44.258 * *$ & 19.495 & 23.054 & $50.597 * *$ \\
\hline High Fees Dummy & 0.078 & 0.056 & -0.502 & 0.019 & $-1.288 * * *$ & 0.995 \\
\hline \% Low Income Counties & 0.152 & 0.360 & -1.665 & -0.340 & $8.810 * * *$ & $-4.737 * *$ \\
\hline \% Independent Directors & -0.125 & $-1.688 * *$ & 3.758 & -2.593 & $7.330 *$ & 6.873 \\
\hline \% Female \& Minority Directors & $0.651 * *$ & $-1.634 * * *$ & 1.689 & -1.533 & 4.226 & $-8.122 * *$ \\
\hline CEO-Chair Duality & -0.157 & -0.027 & 1.714 & -0.305 & 0.438 & 0.415 \\
\hline Director Tenure & 0.010 & $-0.050 * * *$ & $-0.198 *$ & -0.061 & -0.143 & -0.147 \\
\hline Constant & $-2.890 *$ & $15.593 * * *$ & $-57.063 * * *$ & $-18.947 * *$ & $-67.867^{* * *}$ & $-53.960 * * *$ \\
\hline Adjusted R-Squared & 0.59 & 0.44 & 0.61 & 0.24 & 0.96 & 0.85 \\
\hline $\mathrm{N}$ & 113 & 113 & 74 & 74 & 24 & 24 \\
\hline
\end{tabular}




\section{Table 6}

\section{Corporate Social Responsibility Regressions by Size Group - Low Income Concentration}

This table reports regression results in which we examine determinants of Corporate Social Responsibility ESG ratings by size of the sample banks. Low income dummy is equal to 1 if the percentage of low income counties served is above the sample median, and 0 otherwise. Panel A includes banks with low concentration in low income communities. Panel B includes banks with high concentration in low income communities. We collect environmental, social, and governance (ESG) ratings of largest 3,000 publicly traded companies from MSCI ESG STATS. We then merge the ESG ratings data for financial institutions with the Consolidated Report of Condition and Income (i.e., Call Reports) database from Federal Financial Institutions Examination Council (FFIEC). This combined dataset is the base for all our analyses. ${ }^{* * *} \mathrm{p}<0.01,{ }^{* *} \mathrm{p}<0.05,{ }^{*}$ $\mathrm{p}<0.10$.

Panel A: Little Concentration in Low Income Communities

\begin{tabular}{lllllll}
\hline & \multicolumn{2}{c}{ Banks with TA<\$10B } & \multicolumn{2}{c}{ Banks with $\$ 10 \mathrm{~B}<=\mathrm{TA}<\$ 100 \mathrm{~B}$} & \multicolumn{2}{c}{ Banks with TA $>=\$ 100 \mathrm{~B}$} \\
& All Strengths & All Concerns & All Strengths & All Concerns & All Strengths & All Concerns \\
\hline Log Total Assets & $0.256^{* *}$ & 0.039 & $1.463^{* * *}$ & $0.961^{* *}$ & $5.601^{* * *}$ & $3.658^{* * *}$ \\
ROA Industry Adjusted & 1.663 & $-2.806^{* *}$ & $71.378^{* *}$ & -8.576 & -12.151 & 25.142 \\
Tier 1 Capital Ratio & $3.849^{* * *}$ & $2.173^{* * *}$ & $29.489^{* *}$ & $21.109^{* *}$ & -51.985 & -15.341 \\
High Fees Dummy & -0.259 & -0.207 & -0.223 & -0.375 & 0.617 & 0.194 \\
Post Crisis Dummy & $-1.198^{* * *}$ & $1.325^{* * *}$ & -0.304 & -0.152 & $5.348^{*}$ & 0.088 \\
Constant & $-2.931^{*}$ & -0.138 & $-25.570^{* * *}$ & $-16.780^{* * *}$ & $-98.340^{* *}$ & $-65.744^{* *}$ \\
\hline Adjusted R-Squared & 0.18 & 0.29 & 0.36 & 0.26 & 0.76 & 0.69 \\
$\mathrm{~N}$ & 675 & 675 & 165 & 165 & 22 & 22 \\
\hline
\end{tabular}

Panel B: High Concentration in Low Income Communities

\begin{tabular}{lllllll}
\hline & \multicolumn{2}{c}{ Banks with TA $<\$ 10 \mathrm{~B}$} & \multicolumn{2}{c}{ Banks with $\$ 10 \mathrm{~B}<=\mathrm{TA}<\$ 100 \mathrm{~B}$} & \multicolumn{2}{c}{ Banks with TA $>=\$ 100 \mathrm{~B}$} \\
& All Strengths & All Concerns & All Strengths & All Concerns & All Strengths & All Concerns \\
\hline Log Total Assets & 0.075 & 0.059 & $2.252^{* * *}$ & $0.842^{* * *}$ & $3.703^{* * *}$ & $2.772^{* * *}$ \\
ROA Industry Adjusted & 2.433 & 4.668 & 8.517 & $14.088^{* *}$ & $49.875^{* *}$ & 9.781 \\
Tier 1 Capital Ratio & 0.831 & 0.604 & $19.443^{* *}$ & $11.206^{*}$ & $24.026^{*}$ & -3.639 \\
High Fees Dummy & -0.107 & 0.086 & 0.485 & -0.168 & $-2.890^{* * *}$ & $-1.075^{* * *}$ \\
Post Crisis Dummy & $-1.089 * * *$ & $1.167 * * *$ & -0.289 & 0.321 & $1.876^{* * *}$ & $-1.376^{* *}$ \\
Constant & 0.056 & -0.239 & $-38.339^{* * *}$ & $-14.148^{* * *}$ & $-66.410^{* * *}$ & $-48.660^{* * *}$ \\
\hline Adjusted R-Squared & 0.16 & 0.20 & 0.34 & 0.27 & 0.85 & 0.79 \\
$\mathrm{~N}$ & 606 & 606 & 162 & 162 & 82 & 82 \\
\hline
\end{tabular}




\section{Table 7}

\section{Corporate Social Responsibility Regressions by Size Group - Low Income Concentration, Subsample with Governance Variables}

This table reports regression results in which we examine determinants of Corporate Social Responsibility ESG ratings by size of the sample banks. Low income dummy is equal to 1 if the percentage of low income counties served is above the sample median, and 0 otherwise. Panel A includes banks with low concentration in low income communities. Panel B includes banks with high concentration in low income communities. We collect environmental, social, and governance (ESG) ratings of largest 3,000 publicly traded companies from MSCI ESG STATS. We then merge the ESG ratings data for financial institutions with the Consolidated Report of Condition and Income (i.e., Call Reports) database from Federal Financial Institutions Examination Council (FFIEC). This combined dataset is the base for all our analyses. Measures of board composition are collected from RiskMetrics Directors database, supplemented with data collected from proxy statements when RiskMetrics data were not available. ${ }^{* * *} \mathrm{p}<0.01, * * \mathrm{p}<0.05, * \mathrm{p}<0.10$.

Panel A: Low Concentration in Low Income Communities

\begin{tabular}{lllllll}
\hline & \multicolumn{2}{c}{ Banks with TA $<\$ 10 \mathrm{~B}$} & \multicolumn{2}{c}{ Banks with $\$ 10 \mathrm{~B}<=\mathrm{TA}<\$ 100 \mathrm{~B}$} & \multicolumn{2}{c}{ Banks with TA $>=\$ 100 \mathrm{~B}$} \\
& All Strengths & All Concerns & All Strengths & All Concerns & All Strengths & All Concerns \\
\hline Log Total Assets & 0.234 & 0.037 & $1.583^{* * *}$ & $0.966^{* *}$ & $7.394^{* * *}$ & $5.431^{* * *}$ \\
ROA Industry Adjusted & 2.412 & -3.023 & $66.647^{* *}$ & -20.036 & 144.362 & $194.879^{*}$ \\
Tier 1 Capital Ratio & $4.396^{* * *}$ & $2.188^{*}$ & $32.319^{* *}$ & $31.964^{* * *}$ & -117.800 & -86.927 \\
High Fees Dummy & -0.143 & -0.336 & -0.065 & -0.497 & $3.401^{*}$ & 0.647 \\
\% Independent Directors & 0.630 & -0.485 & -0.874 & -0.311 & 12.651 & 6.806 \\
\% Female \& Minority Directors & $3.023^{* * *}$ & -0.102 & $4.169^{* * *}$ & $-1.449^{* * *}$ & -0.404 & -9.440 \\
CEO-Chair Duality & 0.255 & 0.303 & 0.586 & $0.426^{*}$ & -1.674 & -1.343 \\
Director Tenure & -0.008 & 0.004 & -0.069 & 0.005 & 0.680 & 0.282 \\
Post Crisis Dummy & $-1.199^{* * *}$ & $0.826 * * *$ & -0.584 & -0.379 & 2.172 & 1.100 \\
Constant & -3.639 & 0.353 & $-27.894 * * *$ & $-17.662^{* * *}$ & $-144.223^{* * *}$ & $-98.647^{* * *}$ \\
\hline Adjusted R-Squared & 0.29 & 0.10 & 0.45 & 0.29 & 0.79 & 0.77 \\
$\mathrm{~N}$ & 255 & 255 & 146 & 146 & 18 & 18 \\
\hline
\end{tabular}


Panel B: High Concentration in Low Income Communities

\begin{tabular}{lllllll}
\hline & \multicolumn{2}{c}{ Banks with TA $<\$ 10 \mathrm{~B}$} & \multicolumn{2}{c}{ Banks with $\$ 10 \mathrm{~B}<=\mathrm{TA}<\$ 100 \mathrm{~B}$} & \multicolumn{2}{c}{ Banks with TA $>=\$ 100 \mathrm{~B}$} \\
& All Strengths & All Concerns & All Strengths & All Concerns & All Strengths & All Concerns \\
\hline Log Total Assets & 0.087 & 0.049 & $2.329^{* * *}$ & $0.683^{* * *}$ & $3.406^{* * *}$ & $2.742^{* * *}$ \\
ROA Industry Adjusted & $7.071^{*}$ & 5.986 & 17.545 & $21.212^{* *}$ & $24.434^{*}$ & 21.469 \\
Tier 1 Capital Ratio & -1.124 & -4.375 & $16.855^{* *}$ & $13.085^{* *}$ & 20.749 & -6.920 \\
High Fees Dummy & -0.144 & 0.126 & 0.531 & -0.179 & $-2.963^{* * *}$ & $-1.124^{* *}$ \\
\% Independent Directors & 0.510 & 0.421 & -0.459 & 1.121 & $-4.739^{*}$ & 0.123 \\
\% Female \& Minority Directors & $1.953^{* * *}$ & $-1.655^{* * *}$ & 1.435 & -0.155 & $6.399^{*}$ & -1.278 \\
CEO-Chair Duality & -0.021 & -0.051 & -0.338 & 0.428 & -0.323 & 0.368 \\
Director Tenure & 0.013 & 0.013 & -0.050 & $-0.081^{* * *}$ & 0.068 & $-0.133^{* *}$ \\
Post Crisis Dummy & $-1.241^{* * *}$ & $1.116^{* * *}$ & -0.214 & 0.299 & $2.328^{* * *}$ & $-1.355^{* *}$ \\
Constant & -0.427 & 0.150 & $-38.637^{* * *}$ & $-11.942^{* * *}$ & $-58.646^{* * *}$ & $-46.596^{* * *}$ \\
\hline Adjusted R-Squared & 0.31 & 0.23 & 0.37 & 0.33 & 0.89 & 0.80 \\
$\mathrm{~N}$ & 273 & 273 & 145 & 145 & 81 & 81 \\
\hline
\end{tabular}




\section{Table 8}

\section{Financial Performance Regressions by Size Group}

This table reports IV-GMM regression results in which we examine determinants of financial performance by size group. Sample is based on the subset of banks with governance variables. Panel A includes banks with total assets less than $\$ 10$ billion. Panel B includes banks with total assets $\$ 10$ billion and $\$ 100$ billion. Panel C includes banks with total assets greater than $\$ 100$ billion. As instruments, we use Post Crisis Dummy, Log Total Assets, Tier 1 Capital Ratio, High Fees Dummy, Percentage of Low Income Counties, Percentage of Independent Directors, CEO-Chair Duality, Median Tenure of Directors, and Percentage of Female and Minority Directors. We collect environmental, social, and governance (ESG) ratings of largest 3,000 publicly traded companies from MSCI ESG STATS. We then merge the ESG ratings data for financial institutions with the Consolidated Report of Condition and Income (i.e., Call Reports) database from Federal Financial Institutions Examination Council (FFIEC). This combined dataset is the base for all our analyses. *** $\mathrm{p}<0.01$, ** $\mathrm{p}<0.05$, * $\mathrm{p}<0.10$.

\section{Panel A: Banks with total assets less than $\$ 10$ billion}

\begin{tabular}{|c|c|c|c|c|c|c|}
\hline & $\begin{array}{l}\text { (1) } \\
\text { ROA Industry } \\
\text { Adjusted }\end{array}$ & $\begin{array}{l}(2) \\
\text { ROA Industry } \\
\text { Adjusted }\end{array}$ & $\begin{array}{l}\text { (3) } \\
\text { ROA Industry } \\
\text { Adjusted }\end{array}$ & $\begin{array}{l}\text { (4) } \\
\text { ROE Industry } \\
\text { Adjusted }\end{array}$ & $\begin{array}{l}\text { (5) } \\
\text { ROE Industry } \\
\text { Adjusted }\end{array}$ & $\begin{array}{l}(6) \\
\text { ROE Industry } \\
\text { Adjusted }\end{array}$ \\
\hline Lag ROA & $0.287 * * *$ & $0.279 * * *$ & $0.286 * * *$ & & & \\
\hline Lag ROE & & & & $0.672 * * *$ & $0.660 * * *$ & $0.685 * * *$ \\
\hline Crisis Dummy & $-0.005 * * *$ & $-0.005^{* * *}$ & $-0.005 * * *$ & $-0.051 * * *$ & $-0.051 * * *$ & $-0.049 * * *$ \\
\hline ESG Index & -0.001 & & & -0.003 & & \\
\hline All Strengths & & -0.001 & & & -0.006 & \\
\hline All Concerns & & & 0.001 & & & 0.007 \\
\hline Constant & 0.000 & 0.001 & -0.001 & -0.002 & 0.004 & -0.009 \\
\hline Adjusted R-squared & 0.05 & 0.05 & 0.05 & 0.18 & 0.17 & 0.18 \\
\hline $\mathrm{N}$ & 521 & 521 & 521 & 521 & 521 & 521 \\
\hline Angrist-Pischke F-statistic & $23.70 * * *$ & $21.09 * * *$ & $7.25 * * *$ & $22.61 * * *$ & $21.66 * * *$ & $7.90 * * *$ \\
\hline Hansen-J Chi-sq statistic & 8.03 & 7.44 & 8.45 & 6.15 & 5.90 & 6.46 \\
\hline
\end{tabular}


Panel B: Banks with total assets between $\$ 10$ billion and $\$ 100$ billion

\begin{tabular}{|c|c|c|c|c|c|c|}
\hline & $\begin{array}{l}\text { (1) } \\
\text { ROA Industry } \\
\text { Adjusted }\end{array}$ & $\begin{array}{l}(2) \\
\text { ROA Industry } \\
\text { Adjusted }\end{array}$ & $\begin{array}{l}(3) \\
\text { ROA Industry } \\
\text { Adjusted }\end{array}$ & $\begin{array}{l}(4) \\
\text { ROE Industry } \\
\text { Adjusted }\end{array}$ & $\begin{array}{l}\text { (5) } \\
\text { ROE Industry } \\
\text { Adjusted }\end{array}$ & $\begin{array}{l}\text { (6) } \\
\text { ROE Industry } \\
\text { Adjusted }\end{array}$ \\
\hline Lag ROA & $0.672 * * *$ & $0.661^{* * *}$ & $0.669 * * *$ & & & \\
\hline Lag ROE & & & & $0.505^{* * *}$ & $0.502 * * *$ & $0.530 * * *$ \\
\hline Crisis Dummy & -0.000 & -0.000 & -0.000 & -0.006 & -0.007 & -0.008 \\
\hline ESG Index & -0.000 & & & -0.003 & & \\
\hline All Strengths & & -0.000 & & & -0.003 & \\
\hline All Concerns & & & -0.000 & & & -0.008 \\
\hline Constant & -0.000 & 0.000 & -0.000 & 0.003 & 0.008 & 0.012 \\
\hline Adjusted R-squared & 0.35 & 0.35 & 0.35 & 0.17 & 0.17 & 0.14 \\
\hline $\mathrm{N}$ & 283 & 283 & 283 & 283 & 283 & 283 \\
\hline Angrist-Pischke F-statistic & $3.53 * * *$ & $7.69 * * *$ & $2.83 * * *$ & $3.69 * * *$ & $8.14 * * *$ & $2.70^{* *}$ \\
\hline Hansen-J Chi-sq statistic & 12.51 & 12.37 & 12.44 & 11.01 & 10.94 & 11.23 \\
\hline
\end{tabular}

Panel C: Banks with total assets greater than $\$ 100$ billion

\begin{tabular}{|c|c|c|c|c|c|c|}
\hline & $\begin{array}{l}\text { (1) } \\
\text { ROA Industry } \\
\text { Adjusted }\end{array}$ & $\begin{array}{l}(2) \\
\text { ROA Industry } \\
\text { Adjusted }\end{array}$ & $\begin{array}{l}(3) \\
\text { ROA Industry } \\
\text { Adjusted }\end{array}$ & $\begin{array}{l}(4) \\
\text { ROE Industry } \\
\text { Adjusted }\end{array}$ & $\begin{array}{l}\text { (5) } \\
\text { ROE Industry } \\
\text { Adjusted }\end{array}$ & $\begin{array}{l}\text { (6) } \\
\text { ROE Industry } \\
\text { Adjusted }\end{array}$ \\
\hline Lag ROA & $0.388 * * *$ & $0.369 * * *$ & $0.377 * * *$ & & & \\
\hline Lag ROE & & & & $0.313^{* * *}$ & $0.369 * * *$ & $0.398 * * *$ \\
\hline Crisis Dummy & -0.002 & $-0.002 * *$ & $-0.002 * *$ & -0.012 & -0.009 & -0.009 \\
\hline ESG Index & $0.0002 * * *$ & & & $0.002 * * *$ & & \\
\hline All Strengths & & $0.0001 * *$ & & & $0.001 * *$ & \\
\hline All Concerns & & & -0.000 & & & 0.000 \\
\hline Constant & -0.000 & -0.000 & 0.000 & -0.006 & -0.006 & 0.001 \\
\hline Adjusted R-squared & 0.13 & 0.13 & 0.11 & 0.14 & 0.13 & 0.12 \\
\hline $\mathrm{N}$ & 98 & 98 & 98 & 98 & 98 & 98 \\
\hline Angrist-Pischke F-statistic & $10.10^{* * *}$ & $43.23 * * *$ & $675.28 * * *$ & $10.08 * * *$ & $46.15^{* * *}$ & $1,164.58 * * *$ \\
\hline Hansen-J Chi-sq statistic & 8.23 & 8.53 & 7.91 & 6.89 & 8.00 & 8.70 \\
\hline
\end{tabular}




\section{Table 9}

\section{Financial Performance Regressions by Size Group - No Governance Indicators Included in the CSR Scores}

This table reports IV-GMM regression results in which we examine determinants of financial performance by size group. Sample is based on the subset of banks with governance variables. ESG Index Adjusted, All Strengths Adjusted and All Concerns Adjusted variables are adjusted following Servaes and Tamayo (2013) by removing the corporate governance indicators, and by scaling by maximum strength and concern scores for each category and year. Panel A includes banks with total assets less than $\$ 10$ billion. Panel B includes banks with total assets $\$ 10$ billion and $\$ 100$ billion. Panel C includes banks with total assets greater than $\$ 100$ billion. As instruments, we use Post Crisis Dummy, Log Total Assets, Tier 1 Capital Ratio, High Fees Dummy, Percentage of Low Income Counties, Percentage of Independent Directors, CEO-Chair Duality, Median Tenure of Directors, and Percentage of Female and Minority Directors. We collect environmental, social, and governance (ESG) ratings of largest 3,000 publicly traded companies from MSCI ESG STATS. We then merge the ESG ratings data for financial institutions with the Consolidated Report of Condition and Income (i.e., Call Reports) database from Federal Financial Institutions Examination Council (FFIEC). This combined dataset is the base for all our analyses. ${ }^{* * *} \mathrm{p}<0.01,{ }^{* *} \mathrm{p}<0.05,{ }^{*} \mathrm{p}<0.10$.

\section{Panel A: Banks with total assets less than $\$ 10$ billion}

\begin{tabular}{|c|c|c|c|c|c|c|}
\hline & $\begin{array}{l}\text { (1) } \\
\text { ROA Industry } \\
\text { Adjusted }\end{array}$ & $\begin{array}{l}\text { (2) } \\
\text { ROA Industry } \\
\text { Adjusted }\end{array}$ & $\begin{array}{l}\text { (3) } \\
\text { ROA Industry } \\
\text { Adjusted }\end{array}$ & $\begin{array}{l}\text { (4) } \\
\text { ROE Industry } \\
\text { Adjusted }\end{array}$ & $\begin{array}{l}\text { (5) } \\
\text { ROE Industry } \\
\text { Adjusted }\end{array}$ & $\begin{array}{l}\text { (6) } \\
\text { ROE Industry } \\
\text { Adjusted }\end{array}$ \\
\hline Lag ROA & $0.285^{* * *}$ & $0.272 * * *$ & $0.303 * * *$ & & & \\
\hline Lag ROE & & & & $0.669 * * *$ & $0.656 * * *$ & $0.694 * * *$ \\
\hline Crisis Dummy & $-0.005 * * *$ & $-0.006 * * *$ & $-0.005^{* * *}$ & $-0.052 * * *$ & $-0.051 * * *$ & $-0.048 * * *$ \\
\hline ESG Index Adjusted & -0.012 & & & -0.088 & & \\
\hline All Strengths Adjusted & & -0.022 & & & -0.113 & \\
\hline All Concerns Adjusted & & & 0.037 & & & 0.230 \\
\hline Constant & -0.000 & 0.001 & -0.002 & -0.003 & 0.003 & -0.015 \\
\hline Adjusted R-squared & 0.05 & 0.06 & 0.04 & 0.18 & 0.17 & 0.17 \\
\hline $\mathrm{N}$ & 521 & 521 & 521 & 521 & 521 & 521 \\
\hline Angrist-Pischke F-statistic & $12.67 * * *$ & $10.70^{* * *}$ & $3.89 * * *$ & $11.98 * * *$ & $11.53^{* * *}$ & $4.45^{* * *}$ \\
\hline Hansen-J Chi-sq statistic & 7.32 & 8.33 & 6.22 & 5.75 & 5.87 & 5.79 \\
\hline
\end{tabular}


Panel B: Banks with total assets between $\$ 10$ billion and $\$ 100$ billion

\begin{tabular}{|c|c|c|c|c|c|c|}
\hline & $\begin{array}{l}\text { (1) } \\
\text { ROA Industry } \\
\text { Adjusted }\end{array}$ & $\begin{array}{l}(2) \\
\text { ROA Industry } \\
\text { Adjusted }\end{array}$ & $\begin{array}{l}\text { (3) } \\
\text { ROA Industry } \\
\text { Adjusted }\end{array}$ & $\begin{array}{l}(4) \\
\text { ROE Industry } \\
\text { Adjusted }\end{array}$ & $\begin{array}{l}\text { (5) } \\
\text { ROE Industry } \\
\text { Adjusted }\end{array}$ & $\begin{array}{l}\text { (6) } \\
\text { ROE Industry } \\
\text { Adjusted }\end{array}$ \\
\hline Lag ROA & $0.682 * * *$ & $0.670 * * *$ & $0.667 * * *$ & & & \\
\hline Lag ROE & & & & $0.510 * * *$ & $0.504^{* * *}$ & $0.532 * * *$ \\
\hline Crisis Dummy & -0.000 & -0.000 & -0.001 & -0.007 & -0.009 & -0.010 \\
\hline ESG Index Adjusted & -0.004 & & & -0.039 & & \\
\hline All Strengths Adjusted & & -0.003 & & & -0.047 & \\
\hline All Concerns Adjusted & & & -0.009 & & & -0.188 \\
\hline Constant & -0.000 & -0.000 & 0.000 & 0.002 & 0.006 & 0.013 \\
\hline Adjusted R-squared & 0.35 & 0.35 & 0.35 & 0.17 & 0.17 & 0.14 \\
\hline $\mathrm{N}$ & 283 & 283 & 283 & 283 & 283 & 283 \\
\hline Angrist-Pischke F-statistic & $4.44 * * *$ & $9.81 * * *$ & 1.54 & $4.40 * * *$ & $9.61 * * *$ & 1.54 \\
\hline Hansen-J Chi-sq statistic & 12.82 & 12.54 & 12.39 & 11.19 & 11.16 & 10.95 \\
\hline
\end{tabular}

Panel C: Banks with total assets greater than $\$ 100$ billion

\begin{tabular}{|c|c|c|c|c|c|c|}
\hline & $\begin{array}{l}\text { (1) } \\
\text { ROA Industry } \\
\text { Adjusted }\end{array}$ & $\begin{array}{l}(2) \\
\text { ROA Industry } \\
\text { Adjusted }\end{array}$ & $\begin{array}{l}(3) \\
\text { ROA Industry } \\
\text { Adjusted }\end{array}$ & $\begin{array}{l}(4) \\
\text { ROE Industry } \\
\text { Adjusted }\end{array}$ & $\begin{array}{l}\text { (5) } \\
\text { ROE Industry } \\
\text { Adjusted }\end{array}$ & $\begin{array}{l}\text { (6) } \\
\text { ROE Industry } \\
\text { Adjusted }\end{array}$ \\
\hline Lag ROA & $0.400 * * *$ & $0.355^{* * *}$ & $0.378 * * *$ & & & \\
\hline Lag ROE & & & & $0.385 * * *$ & $0.363 * * *$ & $0.396 * * *$ \\
\hline Crisis Dummy & -0.000 & $-0.002 * *$ & $-0.002 * *$ & -0.003 & -0.010 & -0.009 \\
\hline ESG Index Adjusted & $0.008 * * *$ & & & $0.077 * * *$ & & \\
\hline All Strengths Adjusted & & $0.003 * *$ & & & $0.035 * * *$ & \\
\hline All Concerns Adjusted & & & -0.001 & & & 0.001 \\
\hline Constant & $-0.001 *$ & -0.001 & 0.000 & $-0.010 * *$ & $-0.009 *$ & 0.002 \\
\hline Adjusted R-squared & 0.11 & 0.13 & 0.11 & 0.12 & 0.13 & 0.12 \\
\hline $\mathrm{N}$ & 98 & 98 & 98 & 98 & 98 & 98 \\
\hline Angrist-Pischke F-statistic & $5.59 * * *$ & $30.08 * * *$ & $142.45 * * *$ & $5.56 * * *$ & $30.72 * * *$ & $162.63^{* * *}$ \\
\hline Hansen-J Chi-sq statistic & 6.49 & 8.15 & 7.95 & 6.82 & 7.62 & 8.88 \\
\hline
\end{tabular}




\section{Table 10}

\section{Financial Performance Regressions by Size Group - Only 45 ESG Indicators Used in CSR Scores}

This table reports IV-GMM regression results in which we examine determinants of financial performance by size group. Sample is based on the subset of banks with governance variables. ESG Index Consistent, All Strengths Consistent and All Concerns Consistent variables are constructed using 45 ESG indicators that have been consistently used for 2003-2011 period in the MSCI ESG STATS database. Panel A includes banks with total assets less than $\$ 10$ billion. Panel B includes banks with total assets $\$ 10$ billion and $\$ 100$ billion. Panel C includes banks with total assets greater than $\$ 100$ billion. As instruments, we use Post Crisis Dummy, Log Total Assets, Tier 1 Capital Ratio, High Fees Dummy, Percentage of Low Income Counties, Percentage of Independent Directors, CEO-Chair Duality, Median Tenure of Directors, and Percentage of Female and Minority Directors. We collect environmental, social, and governance (ESG) ratings of largest 3,000 publicly traded companies from MSCI ESG STATS. We then merge the ESG ratings data for financial institutions with the Consolidated Report of Condition and Income (i.e., Call Reports) database from Federal Financial Institutions Examination Council (FFIEC). This combined dataset is the base for all our analyses. ${ }^{* * *} \mathrm{p}<0.01,{ }^{* *}$ $\mathrm{p}<0.05, * \mathrm{p}<0.10$.

\section{Panel A: Banks with total assets less than \$10 billion}

\begin{tabular}{|c|c|c|c|c|c|c|}
\hline & $\begin{array}{l}\text { (1) } \\
\text { ROA Industry } \\
\text { Adjusted }\end{array}$ & $\begin{array}{l}\text { (2) } \\
\text { ROA Industry } \\
\text { Adjusted }\end{array}$ & $\begin{array}{l}\text { (3) } \\
\text { ROA Industry } \\
\text { Adjusted }\end{array}$ & $\begin{array}{l}\text { (4) } \\
\text { ROE Industry } \\
\text { Adjusted }\end{array}$ & $\begin{array}{l}\text { (5) } \\
\text { ROE Industry } \\
\text { Adjusted }\end{array}$ & $\begin{array}{l}\text { (6) } \\
\text { ROE Industry } \\
\text { Adjusted }\end{array}$ \\
\hline Lag ROA & $0.292 * * *$ & $0.270 * * *$ & $0.291 * * *$ & & & \\
\hline Lag ROE & & & & $0.665 * * *$ & $0.630 * * *$ & $0.710 * * *$ \\
\hline Crisis Dummy & $-0.005 * * *$ & $-0.005^{* * *}$ & $-0.006 * * *$ & $-0.051 * * *$ & $-0.050 * * *$ & $-0.048 * * *$ \\
\hline ESG Index Consistent & -0.002 & & & -0.013 & & \\
\hline All Strengths Consistent & & -0.004 & & & -0.017 & \\
\hline All Concerns Consistent & & & 0.003 & & & 0.021 \\
\hline Constant & -0.000 & 0.001 & -0.001 & -0.003 & 0.004 & -0.012 \\
\hline Adjusted R-squared & 0.05 & 0.06 & 0.04 & 0.17 & 0.17 & 0.17 \\
\hline $\mathrm{N}$ & 521 & 521 & 521 & 521 & 521 & 521 \\
\hline Angrist-Pischke F-statistic & $11.76^{* * *}$ & $6.33^{* * *}$ & $5.97 * * *$ & $11.30 * * *$ & $9.69 * * *$ & $8.09 * * *$ \\
\hline Hansen-J Chi-sq statistic & 5.34 & 5.85 & 5.93 & 5.17 & 5.26 & 5.55 \\
\hline
\end{tabular}


Panel B: Banks with total assets between $\$ 10$ billion and $\$ 100$ billion

\begin{tabular}{lllllll}
\hline & $\begin{array}{l}(1) \\
\text { ROA Industry } \\
\text { Adjusted }\end{array}$ & $\begin{array}{l}(2) \\
\text { ROA Industry } \\
\text { Adjusted }\end{array}$ & $\begin{array}{l}\text { (3) } \\
\text { ROA Industry } \\
\text { Adjusted }\end{array}$ & $\begin{array}{l}\text { (4) } \\
\text { ROE Industry } \\
\text { Adjusted }\end{array}$ & $\begin{array}{l}\text { (5) } \\
\text { ROE Industry } \\
\text { Adjusted }\end{array}$ & $\begin{array}{l}\text { ROE Industry } \\
\text { Adjusted }\end{array}$ \\
\hline $\begin{array}{l}\text { Lag ROA } \\
\text { Lag ROE }\end{array}$ & $0.669^{* * *}$ & $0.656^{* * *}$ & $0.683^{* * *}$ & & $0.506^{* * *}$ & $\begin{array}{l}0.502^{* * *} \\
0.526^{* * *}\end{array}$ \\
$\begin{array}{l}\text { Crisis Dummy } \\
\text { ESG Index Consistent }\end{array}$ & -0.000 & -0.000 & -0.000 & -0.006 & -0.006 & -0.006 \\
All Strengths Consistent & -0.000 & & -0.005 & -0.005 & \\
All Concerns Consistent & & -0.000 & & & -0.006 \\
Constant & -0.000 & -0.000 & -0.000 & 0.005 & 0.007 & 0.004 \\
\hline Adjusted R-squared & 0.35 & 0.35 & 0.36 & 0.17 & 0.16 & 0.16 \\
N & 283 & 283 & 283 & 283 & 283 & 283 \\
\hline $\begin{array}{l}\text { Angrist-Pischke F-statistic } \\
\text { Hansen-J Chi-sq statistic }\end{array}$ & $4.02^{* * *}$ & $6.06^{* * *}$ & $3.11^{* * *}$ & $3.95^{* * *}$ & $6.07^{* * *}$ & $3.06^{* * *}$ \\
\hline
\end{tabular}

Panel C: Banks with total assets greater than $\$ 100$ billion

\begin{tabular}{|c|c|c|c|c|c|c|}
\hline & $\begin{array}{l}\text { (1) } \\
\text { ROA Industry } \\
\text { Adjusted }\end{array}$ & $\begin{array}{l}(2) \\
\text { ROA Industry } \\
\text { Adjusted }\end{array}$ & $\begin{array}{l}(3) \\
\text { ROA Industry } \\
\text { Adjusted }\end{array}$ & $\begin{array}{l}(4) \\
\text { ROE Industry } \\
\text { Adjusted }\end{array}$ & $\begin{array}{l}\text { (5) } \\
\text { ROE Industry } \\
\text { Adjusted }\end{array}$ & $\begin{array}{l}\text { (6) } \\
\text { ROE Industry } \\
\text { Adjusted }\end{array}$ \\
\hline Lag ROA & $0.368 * * *$ & $0.364 * * *$ & $0.388 * * *$ & & & \\
\hline Lag ROE & & & & $0.285 * * *$ & $0.350 * * *$ & $0.408 * * *$ \\
\hline Crisis Dummy & $-0.002 *$ & $-0.002 * *$ & $-0.002 * *$ & -0.012 & -0.008 & -0.008 \\
\hline ESG Index Consistent & $0.0002 * * *$ & & & $0.002 * * *$ & & \\
\hline All Strengths Consistent & & $0.0001 * *$ & & & $0.002 * * *$ & \\
\hline All Concerns Consistent & & & -0.000 & & & 0.001 \\
\hline Constant & -0.000 & -0.000 & 0.000 & -0.005 & -0.007 & 0.000 \\
\hline Adjusted R-squared & 0.13 & 0.13 & 0.11 & 0.13 & 0.13 & 0.12 \\
\hline $\mathrm{N}$ & 98 & 98 & 98 & 98 & 98 & 98 \\
\hline Angrist-Pischke F-statistic & $27.05 * * *$ & $92.21 * * *$ & $554.34 * * *$ & $29.81 * * *$ & $91.80 * * *$ & $578.28 * * *$ \\
\hline Hansen-J Chi-sq statistic & 8.27 & 8.48 & 8.28 & 6.19 & 7.28 & 9.09 \\
\hline
\end{tabular}

